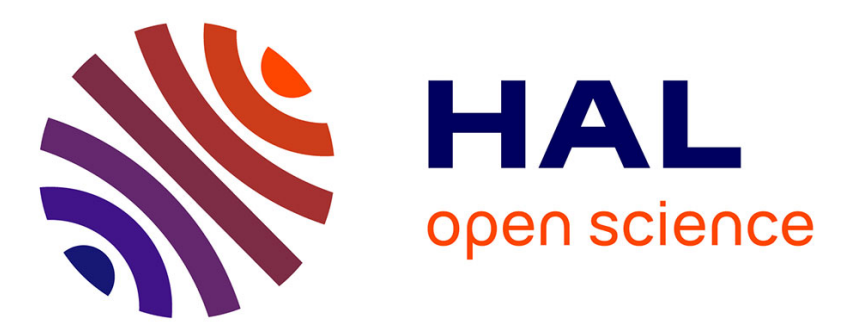

\title{
Determination by reactive absorption of the rate constant of the ozone reaction with the hydroperoxide anion
}

Pierre-Francois Biard, Thom Thi Dang, Annabelle Couvert

\section{- To cite this version:}

Pierre-Francois Biard, Thom Thi Dang, Annabelle Couvert. Determination by reactive absorption of the rate constant of the ozone reaction with the hydroperoxide anion. Chemical Engineering Research and Design, 2017, 127, pp.62-71. 10.1016/j.cherd.2017.09.004 . hal-01652337

HAL Id: hal-01652337

https://hal-univ-rennes1.archives-ouvertes.fr/hal-01652337

Submitted on 30 Nov 2017

HAL is a multi-disciplinary open access archive for the deposit and dissemination of scientific research documents, whether they are published or not. The documents may come from teaching and research institutions in France or abroad, or from public or private research centers.
L'archive ouverte pluridisciplinaire HAL, est destinée au dépôt et à la diffusion de documents scientifiques de niveau recherche, publiés ou non, émanant des établissements d'enseignement et de recherche français ou étrangers, des laboratoires publics ou privés. 


\section{Determination by reactive absorption of the rate constant of the ozone reaction with the hydroperoxide anion}

Pierre-François BIARD ${ }^{a^{*}}$, Thom Thi DANG ${ }^{a, b}$, Annabelle COUVERT ${ }^{a}$

aÉcole Nationale Supérieure de Chimie de Rennes, CNRS, UMR 6226, 11 Allée de Beaulieu, CS 50837, 35708 Rennes Cedex 7, France.

'Institute of Environmental Technology, Vietnam Academy of Science and Technology, 18 Hoangquocviet Road, Hanoi, Vietnam.

*Corresponding author : pierre-francois.biard@ensc-rennes.fr, +33223238149

Graphical abstract

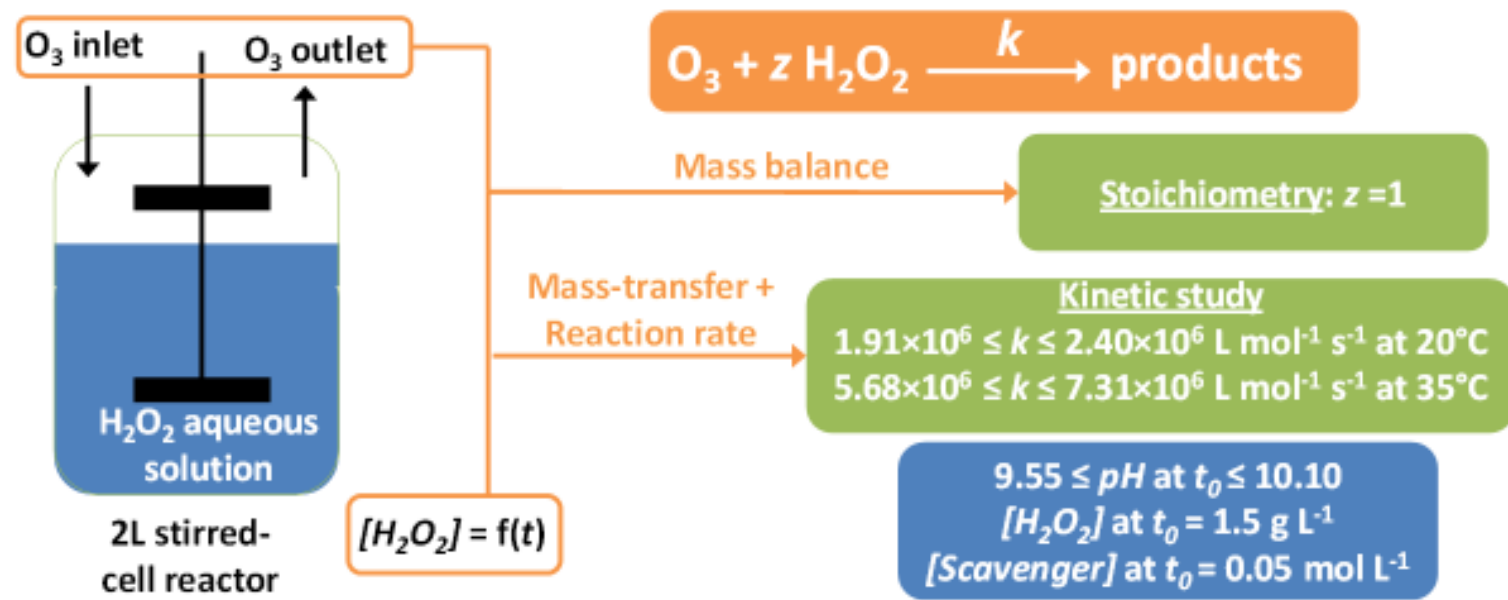




\section{Highlights}

- The reaction rate constant $k$ between $\mathrm{O}_{3}$ and $\mathrm{HO}_{2}{ }^{-}$was determined by reactive absorption

- $k$ is in the range $1.91 \times 10^{6}-2.40 \times 10^{6} \mathrm{~L} \mathrm{~mol}^{-1} \mathrm{~s}^{-1}$ at $20^{\circ} \mathrm{C}$

- $k$ is in the range $5.68 \times 10^{6}-7.31 \times 10^{6} \mathrm{~L} \mathrm{~mol}^{-1} \mathrm{~s}^{-1}$ at $35^{\circ} \mathrm{C}$

- An activation energy in the range $45-69 \mathrm{~kJ} \mathrm{~mol}^{-1}$ was determined.

\section{Abstract}

The reaction rate constant between the hydroperoxide anion $\left(\mathrm{HO}_{2}{ }^{-}\right)$and molecular ozone was evaluated from the reactive absorption method in the range of temperature from 20 to $35^{\circ} \mathrm{C}$. This reaction is crucial in the initiation step of the ozone decomposition, especially using the peroxone process which combines ozone and hydrogen peroxide in solution. A stirred-cell operated semicontinuously was used for this purpose. A high initial concentration of tert-butanol $\left(0.05 \mathrm{~mol} \mathrm{~L}^{-1}\right)$ was applied to efficiently scavenge all radicals and to avoid any parasite reaction. Based on the dissolved $\mathrm{H}_{2} \mathrm{O}_{2}$ concentration decreasing and the outlet ozone concentration time-course, the stoichiometry of the initiation reaction was determined, with one mol of $\mathrm{H}_{2} \mathrm{O}_{2}$ consumed per mol of ozone transferred. The chemical conditions were thoroughly selected to reach a fast pseudo-first order absorption regime. The reaction rate constant increased from $1.91 \times 10^{6}-2.40 \times 10^{6} \mathrm{~L} \mathrm{~mol}^{-1} \mathrm{~s}^{-1}$ at $20^{\circ} \mathrm{C}$ to $5.68 \times 10^{6}-7.31 \times 10^{6} \mathrm{~L} \mathrm{~mol}^{-1} \mathrm{~s}^{-1}$ at $35^{\circ} \mathrm{C}$.

\section{Keywords:}

Reactive absorption; ozone; hydrogen peroxide; initiation; rate constant; activation energy

\section{Nomenclature}

$C_{G}$ : gaseous ozone concentration (read in $\mathrm{g} \mathrm{Nm}^{-3}$ and converted in $\mathrm{mol} \mathrm{m}^{-3}$ ) 
$C_{L}$ : dissolved ozone concentration $\left(\mathrm{mol} \mathrm{m}^{-3}\right)$

$C_{R}$ : total reactant $\left(\mathrm{H}_{2} \mathrm{O}_{2}+\mathrm{HO}_{2}^{-}\right)$bulk concentration (mol L-1 or g $\mathrm{L}^{-1}$ )

$C_{S}$ : scavenger (tert-butanol) bulk concentration $\left(\mathrm{mol} \mathrm{L}^{-1}\right)$

$D_{L}$ : ozone diffusion coefficient at infinite dilution in the liquid phase $\left(\mathrm{m}^{2} \mathrm{~s}^{-1}\right)$

$D_{R}$ : reactant diffusion coefficient at infinite dilution in the liquid phase $\left(\mathrm{m}^{2} \mathrm{~s}^{-1}\right)$

$E$ : enhancement (reaction) factor (dimensionless)

$E_{i}$ : instantaneous enhancement (reaction) factor (dimensionless)

El: elasticity index (dimensionless)

$F_{G}$ : gas flow rate (read and corrected in $\mathrm{NL} \mathrm{h}^{-1}$ and further converted in $\mathrm{Nm}^{3} \mathrm{~s}^{-1}$ and $\mathrm{m}^{3} \mathrm{~s}^{-1}$ )

$H$ : ozone Henry's law constant in water $\left(\mathrm{Pa} \mathrm{m}^{3} \mathrm{~mol}^{-1}\right)$

$H a:$ Hatta number (dimensionless)

I: inputs of the model

$\mathrm{J}$ : mass-transfer rate $\left(\mathrm{mol} \mathrm{s}^{-1}\right)$

$k$ : second-order reaction rate constant $\left(\mathrm{L} \mathrm{mol}^{-1} \mathrm{~s}^{-1}\right)$

$k^{\prime}$ : pseudo-first order reaction constant calculated for any species i by $k_{\mathrm{HO} \%} \times[i]\left(\mathrm{s}^{-1}\right)$

$k_{G}$ : gas-phase mass-transfer coefficient $\left(\mathrm{m} \mathrm{s}^{-1}\right)$

$k_{L}$ : liquid-phase mass-transfer coefficient $\left(\mathrm{m} \mathrm{s}^{-1}\right)$

$K_{L}$ : overall liquid-phase mass-transfer coefficient $\left(\mathrm{m} \mathrm{s}^{-1}\right)$

$M_{i}$ : molar mass of any compound i $\left(\mathrm{g} \mathrm{mol}^{-1}\right)$

$N$ : stirring speed (rpm)

$n_{R}$ : reactant $\left(\mathrm{H}_{2} \mathrm{O}_{2}+\mathrm{HO}_{2}^{-}\right)$amount $(\mathrm{mol})$ in the reactor

$O$ : output of the model

OF: objective function (according to Eq. 20)

$P$ : pressure in the reactor (bar)

$\mathrm{R}$ : ideal gas constant $\left(8.314 \mathrm{~J} \mathrm{~mol}^{-1} \mathrm{~K}^{-1}\right)$

$R E(\%)$ : relative error

$R S D(\%)$ : relative standard deviations

$S$ : gas-liquid interfacial area $\left(\mathrm{m}^{2}\right)$

$t$ : time (s)

$T$ : Temperature $\left(\mathrm{K}\right.$ or $\left.{ }^{\circ} \mathrm{C}\right)$

$V$ : liquid volume (L)

z: stoichiometric coefficient corresponding to the amount of $\mathrm{H}_{2} \mathrm{O}_{2}$ consumed per amount of $\mathrm{O}_{3}$ consumed

\section{Greek letters:}


$\Delta t$ : time path (s)

$\sigma$. standard deviation

\section{Subscripts:}

$\mathrm{G} / \mathrm{L}$ : relative to the gas or the liquid

i/o: at the inlet or at the outlet

I: relative to the reactant $\left(\mathrm{H}_{2} \mathrm{O}_{2}\right)$ lost

$\mathrm{R}$ : relative to the reactant

0 : at the initial time

$\mathrm{f}$ : at the final time $(1 \mathrm{~h})$

\section{Superscripts:}

*: at the interface

eq: at the equilibrium

$\mathrm{t}$ : at the time $\mathrm{t}$

\section{Introduction}

Chemical oxidation and disinfection using ozone are currently implemented in drinking and waste water treatment plants (Von Sonntag and Von Gunten, 2012). Besides its direct reactivity with inorganic and organic compounds, a significant part of the ozone reactivity in water is based on indirect reactions with radicals generated by the ozone decomposition $\left(\mathrm{HO}^{\circ}, \mathrm{HO}_{2}{ }^{\circ}, \mathrm{O}_{2}{ }^{\circ}\right.$, etc.) (Beltrán, 2004; Von Gunten, 2003; Von Sonntag and Von Gunten, 2012).

The indirect mechanism is often targeted to enhance the radical formation, especially of hydroxyl radicals $\left(\mathrm{HO}^{\circ}\right)$ which are particularly reactive and non-selective (Glaze and Kang, 1989; Glaze et al., 
1987; Von Gunten, 2003). Thus, the peroxone process, which combines hydrogen peroxide and ozone in solution, is efficiently used for micropollutant (pesticides, drugs, endocrine disruptors, etc.) oxidation (Acero and Von Gunten, 2001). This process is based on the fast ozone decomposition initiation reaction with the hydroperoxide anion $\left(\mathrm{HO}_{2}^{-}\right)$. This anion is the $\mathrm{H}_{2} \mathrm{O}_{2}$ conjugated base $(p K a \approx$ 11.75 at $20^{\circ} \mathrm{C}$ (Evans and Uri, 1949)).

The reaction between $\mathrm{O}_{3}$ and $\mathrm{HO}_{2}^{-}$is described in the literature as a proton transfer reaction or as an adduct formation reaction. The reaction between $\mathrm{H}_{2} \mathrm{O}_{2}$ and $\mathrm{O}_{3}$ is unlikely (Staehelin and Hoigne, 1982; Taube and Bray, 1940). Thus, according to Staehelin and Hoigné (1982), as well as Tomiyasu et al. (1985), hydroperoxide anion initiates the ozone decomposition according to respectively Eqs. 1 and 2 (Staehelin and Hoigne, 1982; Tomiyasu et al., 1985):

$$
\begin{aligned}
& \mathrm{O}_{3}+\mathrm{HO}_{2}{ }^{-} \stackrel{\mathrm{k}=2.8 \times 10^{6} \mathrm{Lmol}^{1} \mathrm{~s}^{-1} \text { at } 20^{\circ} \mathrm{C}}{\longrightarrow} \mathrm{HO}^{\circ}+\mathrm{O}_{2}{ }^{\circ-}+\mathrm{O}_{2} \\
& \mathrm{O}_{3}+\mathrm{HO}_{2}{ }^{-} \stackrel{\mathrm{k}=2.2 \times 10^{6} \mathrm{Lmol}^{-1} \mathrm{~s}^{-1} \text { at } 20^{\circ} \mathrm{C}}{\longrightarrow} \mathrm{HO}_{2}{ }^{\circ}+\mathrm{O}_{3}{ }^{-\circ}
\end{aligned}
$$

All the radicals formed can be involved in several propagation or termination reactions (Buehler et al., 1984a; Buehler et al., 1984b; Mandel et al., 2014; Staehelin et al., 1984; Tomiyasu et al., 1985). These two models support a theoretical stoichiometry of $2 \mathrm{~mol}$ of $\mathrm{O}_{3}$ consumed and $2 \mathrm{~mol}$ of $\mathrm{HO}^{\circ}$ formed for one mol of $\mathrm{H}_{2} \mathrm{O}_{2}$ consumed (Merényi et al., 2010a). However, in real water, the formation of less than one mol of $\mathrm{HO}^{\circ}$ for one mol of $\mathrm{H}_{2} \mathrm{O}_{2}$ consumed is always observed (Fischbacher et al., 2013; Merényi et al., 2010a; Staehelin and Hoigne, 1982). Thus, more recently, the ozone decomposition mechanism has been extensively revisited assuming the reversible formation of the adduct $\mathrm{HO}_{5}{ }^{-}$which is further decomposed into $\mathrm{HO}_{2}{ }^{\circ}+\mathrm{O}_{3}^{-\circ}$ and $2 \mathrm{O}_{3}+\mathrm{HO}^{-}$(Merényi et al., 2010a; Merényi et al., 2010b; Sein et al., 2007) :

$$
\mathrm{O}_{3}+\mathrm{HO}_{2}^{-} \stackrel{\mathrm{k}=4.80 \times 10^{6} \mathrm{~L} \mathrm{~mol}^{-1} \mathrm{~s}^{-1}}{\rightleftharpoons} \mathrm{HO}_{5}^{-} \rightleftharpoons 2 \mathrm{O}_{3}+\mathrm{HO}^{-}
$$


Following the ozone decay in a UV-cell, Staehelin et al. (1982) determined a second-order reaction rate constant $k=(2.8 \pm 0.6) \times 10^{6} \mathrm{~L} \mathrm{~mol}^{-1} \mathrm{~s}^{-1}$ at $20 \pm 1^{\circ} \mathrm{C}$ (Staehelin and Hoigne, 1982). Methylmercury hydroxide was used as radical scavenger. Later, Tomiyasu et al. (1985) confirmed this order of magnitude using advantageously the stopped-flow method with a value of $k=2.2 \times 10^{6} \mathrm{~L} \mathrm{~mol}^{-1} \mathrm{~s}^{-1}$ at $20^{\circ} \mathrm{C}$ (Tomiyasu et al., 1985). No scavenger was used. More recently, Sein et al. (2007) found a value of the apparent reaction rate constant equal to $(4.8 \pm 1.0) \times 10^{6} \mathrm{~L} \mathrm{~mol}^{-1} \mathrm{~s}^{-1}$ at $20 \pm 1^{\circ} \mathrm{C}$ from the ozone decay measured by a spectrophotometer using a large excess $\left(0.01 \mathrm{~mol} \mathrm{~L}^{-1}\right)$ of tert-butanol (Sein et al., 2007). This value should correspond to the forward reaction leading to the formation of the adduct $\mathrm{HO}_{5}{ }^{-}$since it should be the rate limiting step (Gardoni et al., 2012). Different values of the $\mathrm{H}_{2} \mathrm{O}_{2} / \mathrm{HO}_{2}^{-} \mathrm{pKa}$ (in the range from 11.65 to 11.80 ) were considered in these studies, which influences the determination of $k$ (Sein et al., 2007).

The reactive absorption method might be advantageously used to assess the kinetics of this reaction. This method is particularly adapted to reactions with molecular ozone since the dissolved ozone concentration is zero (Dang et al., 2016). Thus, the accuracy of the method is not affected by the poor ozone solubility and stability and its rather inaccurate quantification (Beltrán, 2004; Beltrán et al., 1998; Cardona et al., 2010; Dang et al., 2016; Sotelo et al., 1990; Sotelo et al., 1991). The calculation of the enhancement (or reaction) factor $E$, deduced from both the mass-transfer and chemical reaction rates, is the basis of the method (Beltrán, 2004). Stirred-cell reactors, in which the interfacial area is well known from the reactor geometry, are particularly appealing for ozonation studies (Dang et al., 2016). Nonetheless, the gas-side resistance might be significant, even using a poorly soluble compound such as $\mathrm{O}_{3}$, especially when a fast chemical reaction is involved in the liquid phase (Dang et al., 2016). To reduce the number of inputs of the model and to gain in accuracy, the pseudo-first order regime is recommended (Dang et al., 2016). In that case, the reactant concentration near the gas-liquid interface is equal to the bulk concentration (Beltrán, 2004; Bin and Roustan, 2000; Luzi et al., 2014; Vaidya and Kenig, 2007). Furthermore, the mass-transfer rate is 
uninfluenced by the liquid-phase mass-transfer coefficient $k_{L}$ and the reactant diffusion coefficient $D_{R}$.

The knowledge of the reaction rate constant between $\mathrm{O}_{3}$ and $\mathrm{HO}_{2}^{-}$is crucial for both fundamental (ozone decomposition modeling) and industrial purposes (reactor design). However, its value is still uncertain at $20^{\circ} \mathrm{C}$ and is unknown at other temperatures. Consequently, the purpose of this study is to assess the evolution of this reaction rate constant from 20 to $35^{\circ} \mathrm{C}$ by using the reactive absorption kinetic method in a temperature controlled stirred-cell reactor operated semi-continuously.

\section{Material and methods}

\subsection{Reactor and experimental set-up description}

Table 1: Experimental operating conditions, mass-transfer coefficients and surface area of the stirred-cell reactor.

\begin{tabular}{|c|c|c|c|c|c|c|c|c|c|}
\hline \multicolumn{10}{|c|}{ Experimental conditions } \\
\hline$T$ & $P$ & $V$ & $F_{G}$ & $N$ & $C_{G, i}$ & $C_{R}$ at $t_{0}$ & $C_{R}$ at $t_{0}$ & $p H$ at $t_{0}$ & $C_{s}$ at $t_{0}$ \\
\hline${ }^{\circ} \mathrm{C}$ & bar & L & $\mathrm{NL} \mathrm{h}^{-1}$ & rpm & $\mathrm{g} \mathrm{Nm}^{-3}$ & $\mathrm{~g} \mathrm{~L}^{-1}$ & $\mathrm{~mol} \mathrm{~L}^{-1}$ & & $\mathrm{~mol} \mathrm{~L}^{-1}$ \\
\hline $20-35$ & $\approx 1$ & $\approx 1.3$ & $68.5 \pm 0.5$ & 160 & $33-95$ & 1.55 & 0.0456 & $9.55-10.10$ & 0.050 \\
\hline \multicolumn{10}{|c|}{ Mass-transfer coefficients and surface area according to (Dang et al., 2016) } \\
\hline \multicolumn{4}{|c|}{$10^{5} \times k_{L}\left(\mathrm{~m} \mathrm{~s}^{-1}\right)$} & \multicolumn{4}{|c|}{$10^{3} \times k_{G}\left(\mathrm{~m} \mathrm{~s}^{-1}\right)$} & \multirow{2}{*}{\multicolumn{2}{|c|}{ Interfacial area $S\left(\mathrm{~m}^{2}\right)$}} \\
\hline $20^{\circ} \mathrm{C}$ & $25^{\circ} \mathrm{C}$ & $30^{\circ} \mathrm{C}$ & $35^{\circ} \mathrm{C}$ & $20^{\circ} \mathrm{C}$ & $25^{\circ} \mathrm{C}$ & $30^{\circ} \mathrm{C}$ & $35^{\circ} \mathrm{C}$ & & \\
\hline 1.19 & 1.61 & 1.77 & 1.75 & 3.95 & 4.40 & 4.86 & 4.80 & $7.72 x$ & \\
\hline
\end{tabular}

The $2 \mathrm{~L}$ jacketed stirred-cell reactor, in which the gas and liquid phases were separated by a flat interface, and the experimental set-up have been already described by Dang et al. (2016) and are also provided as a supplementary content. The operating conditions of Dang et al. studies (2016) (pressure $P$ of around 1 bar, $20 \leq T \leq 35^{\circ} \mathrm{C}$, liquid volume $V$ of $1.3 \mathrm{~L}$, stirring speed $N$ of $160 \mathrm{rpm}$, turbines positions, gas flow-rate $F_{G}$ of $\left.68.5 \mathrm{NL} \mathrm{h}^{-1}\right)$ were selected, allowing to reuse their liquid $\left(k_{L}\right)$ and gas-phase $\left(k_{G}\right)$ mass-transfer coefficients (Table 1). All the experiments were performed in ultra 
pure water produced by reverse osmosis (resistivity $<18 \mathrm{M} \Omega \mathrm{cm}$ ) by a Purelab system (Elga, France) containing an initial tert-butanol (Sigma Aldrich, USA, purity $>99 \%$ ) concentration $C_{S}$ of $0.05 \mathrm{~mol} \mathrm{~L}^{-1}$ to scavenge the radical chain. No buffer was added to avoid potential parasite reactions.

\subsection{Experimental protocol}

The semi-batch experiments were conducted at transient state. On the one hand, the gas flow-rate and the ozone inlet concentration remained unchanged during the experiments. On the other hand, the $\mathrm{pH}$, the $\mathrm{H}_{2} \mathrm{O}_{2}$ concentration and the $\mathrm{O}_{3}$ outlet concentration varied during the experiments and were monitored.

First, the stirred-cell reactor was filled with around $1.3 \mathrm{~L}$ of ultra pure water (weighted to know the exact volume introduced), doped with controlled amounts of $\mathrm{H}_{2} \mathrm{O}_{2}\left(C_{R} \approx 1.5 \mathrm{~g} \mathrm{~L}^{-1}\right)$ and $\mathrm{NaOH}(0.1 \mathrm{~mol}$ $\mathrm{L}^{-1}$, provided by Merck, Germany) to set the initial conditions. The temperature of the liquid (in the range from $20^{\circ} \mathrm{C}$ to $35^{\circ} \mathrm{C}$ ) was controlled with a thermostatic bath. The gas-liquid reactor was fed only when the inlet gas ozone concentration $\left(C_{G, i}\right)$, measured by an on-line ozone analyzer (BMT 964

$\mathrm{N}$, Germany), was constant and the time was recorded. Thus, the ozone outlet gas concentration was continuously monitored. Samples of $5 \mathrm{~mL}$ of the liquid phase were withdrawn regularly (every $300 \mathrm{~s}$ ) using a gas-tight syringe ( $\mathrm{SGE}$, Australia) for $\mathrm{H}_{2} \mathrm{O}_{2}$ quantification (by the iodometric titration method) and for $\mathrm{pH}$ measurement (using a $\mathrm{pH} / \mathrm{T}$ combined probe provided by SI Analytics, connected to a WTW 315i pH - meter). The dissolved ozone solution was quantified by the indigo carmine method and was found to be in all cases negligible. After approximately one hour of experiment, the reactor was by-passed to measure once again the inlet ozone gas concentration. Then, the ozone generator was turned off and the solution was drained. At each temperature, five experiments were carriedout with different initial chemical conditions (Table 2).

Table 2: Summary of the experimental conditions relative to each experiment.

\begin{tabular}{cccc|}
\hline Exp. number & $p H$ at $\mathrm{t}_{0}$ & $C_{R}\left(\mathrm{~g} \mathrm{~L}^{-1}\right)$ at $\mathrm{t}_{0}$ & $\boldsymbol{C}_{G, i}\left(\mathrm{~g} \mathrm{Nm}^{-3}\right)$ \\
\hline$\# 1$ & 9.56 & 1.56 & 33.2 \\
\hline
\end{tabular}




\begin{tabular}{|lccc|}
\hline \#2 & 9.74 & 1.56 & 94.3 \\
\hline$\# \mathbf{3}$ & 9.80 & 1.53 & 71.9 \\
\hline$\# \mathbf{4}$ & 9.59 & 1.58 & 71.7 \\
\hline \#5 & 10.09 & 1.54 & 72.4 \\
\hline
\end{tabular}

\section{Results and discussion}

\subsection{Experimental results}
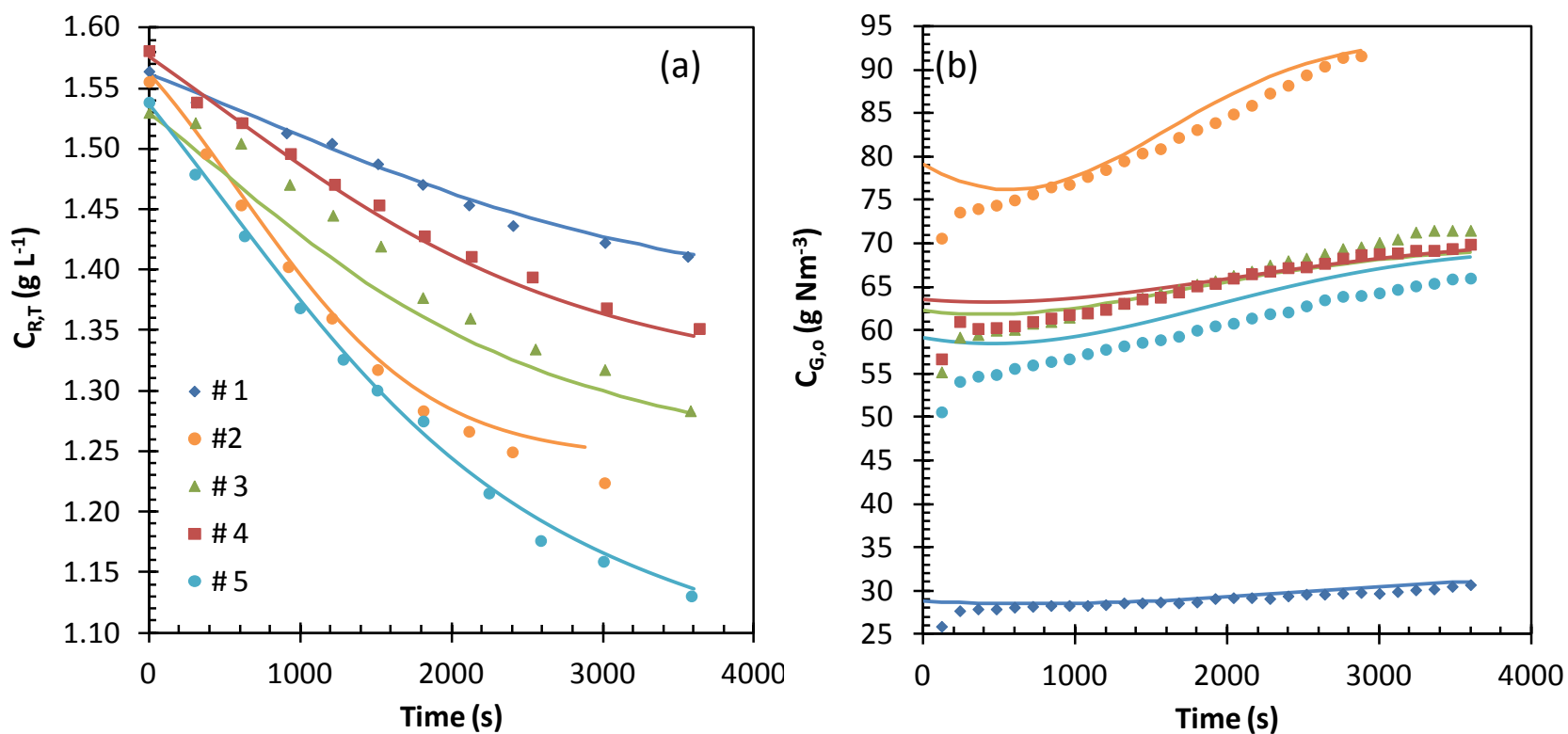

Figure 1: $\mathrm{H}_{2} \mathrm{O}_{2}$ concentration (a) and ozone outlet gas concentration (b) time-courses at $20^{\circ} \mathrm{C}$.

The points correspond to the experimental measurements. The straight curves correspond to the concentrations deduced from the model (section 3.3).

During the experiments, the total $\mathrm{H}_{2} \mathrm{O}_{2}$ concentration $\left(\mathrm{H}_{2} \mathrm{O}_{2}\right.$ is denoted as the reactant $\mathrm{R}$ and $C_{R}=$ $\left[\mathrm{H}_{2} \mathrm{O}_{2}\right]+\left[\mathrm{HO}_{2}^{-}\right]$) dropped. This decreasing was sharper for increasing inlet ozone concentration (Fig 1.a) and higher initial $p H\left(p H_{\# 5}>p H_{\# 3}>p H_{\# 4}\right)$ due to a higher reaction rate. In the meantime, the $\mathrm{pH}$ dropped owing to the $\mathrm{HO}_{2}{ }^{-}$consumption by the reaction (Fig. 2). Both the $\mathrm{pH}$ and $C_{R}$ decreasing led to a lower reaction rate with time. Thus, the outlet ozone gas concentration $\left(C_{G, o}\right)$ slightly increased 
with time (Fig. 1.b). $C_{G, o}$ values below around 5 min were biased due to the dead-time in the analysis line (Dang et al., 2016).

The dissolved ozone concentration was unquantifiable using the indigo-carmine colorimetric method, demonstrating that the ozone was completely consumed near the gas-liquid interface and did not diffuse in the liquid bulk. This behavior is characteristic of the fast absorption regime and is adapted to the reactive absorption method (Beltrán, 2004; Dang et al., 2016).

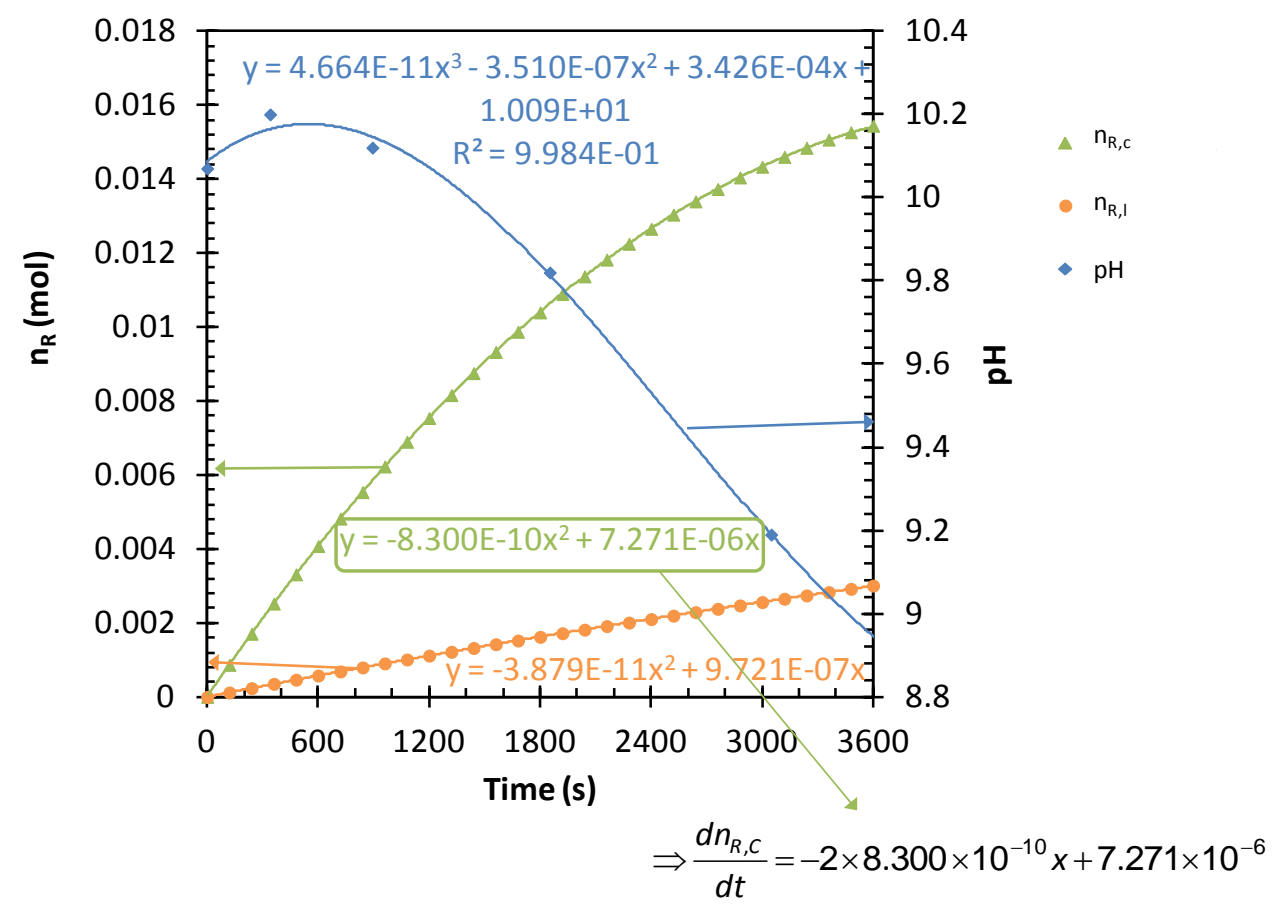

Figure 2: $p H$ (experimental values, blue diamonds), amount of $\mathrm{H}_{2} \mathrm{O}_{2}$ consumed $n_{R, c}$ (deduced according to Eq. 7, green triangles) and amount of $\mathrm{H}_{2} \mathrm{O}_{2}$ lost in samplings $n_{R, I}$ (deduced according to Eq. 6, orange circles) time-courses (Example of exp. \#5 at $20^{\circ} \mathrm{C}$ ). These variables were fitted by polynomial functions represented by the straight curves. 


\subsection{Determination of the reaction stoichiometry}

\subsubsection{Mathematical modeling}

The ozone transferred was entirely consumed near the interface and did not accumulate in the solution (i.e. its concentration in the liquid bulk was zero, $C_{L}=0$ ). $z$ represents the amount of $\mathrm{H}_{2} \mathrm{O}_{2}$ consumed per amount of $\mathrm{O}_{3}$ transferred (and consumed). The ozone mass balance can be written according to Eq. 4:

Gasinlet $=$ Gasoutlet + reaction $\Rightarrow F_{G} \frac{C_{G, i}}{M_{O_{3}}}=F_{G} \frac{C_{G, o}}{M_{O_{3}}}-\frac{1}{Z} \frac{d n_{R}}{d t}$ Eq. 4. The read gas flow rate $F_{G}$ (NL h-1 where $\mathrm{N}$ stands for the standard conditions for temperature and pressure) is corrected with the temperature and the pressure (Dang et al., 2016). $C_{G}$ is the gaseous ozone concentration (read in $\left.\mathrm{g} \mathrm{Nm}^{-3}\right) \cdot C_{R}\left(\mathrm{~g} \mathrm{~L}^{-1}\right)$ and $n_{R}(\mathrm{~mol})$ are respectively the $\mathrm{H}_{2} \mathrm{O}_{2}$ concentration and amount in the liquid bulk. $V$ is the liquid volume (L) whose evolution with time was known since samples of exactly $5 \mathrm{~mL}$ were withdrawn. The conversion of the volume expressed as $\mathrm{NL}$ or $\mathrm{Nm}^{3}$ into the volume at the working temperature and pressure ( $\left.\mathrm{L} \mathrm{or} \mathrm{m}^{3}\right)$ is detailed by Dang et al. (2016). The amount of $\mathrm{H}_{2} \mathrm{O}_{2}$ lost $\left(n_{R, l}\right)$ in the samples withdrawn was significant and considered in the calculation (Fig. 2). Therefore, Eq.4 is rewritten taking account of the amount of $\mathrm{H}_{2} \mathrm{O}_{2}$ really consumed by the reaction (subscript " $c$ "):

$$
\Rightarrow z=\frac{M_{O_{3}}}{F_{G}\left(C_{G, i}-C_{G, o}\right)} \frac{d n_{R, c}}{d t}
$$

$n_{R, l}$ and $n_{R, c}$ at any time $t$ were evaluated by discretization through respectively Eqs 6 and 7:

$$
\begin{aligned}
& n_{R, I}^{t+\Delta t}=n_{R, I}^{t}+\frac{V^{t}-V^{t+\Delta t}}{M_{R}} C_{R} \text { with } n_{R, l}^{t_{0}}=0 \\
& n_{R, c}^{t+\Delta t}=\frac{C_{R}^{t} V^{t}-C_{R}^{t+\Delta t} V^{t+\Delta t}}{M_{R}}-n_{R, l}^{t+\Delta t} \text { with } n_{R, c}^{t_{0}}=0
\end{aligned}
$$


A time path $(\Delta t)$ of $120 \mathrm{~s}$ was considered. The values of $C_{R}^{t}$ used in Eqs 6 and 7 were previously computed by second or third degree polynomial functions fitted to the experimental values of the hydrogen peroxide concentration, with determination coefficients $R^{2}$ higher than $99 \% . n_{R, l}$ and $n_{R, C}$ time-courses were also fitted to second or third degree polynomial functions (Fig. 2). Then, according to Eq. $5, z$ was deduced at any time $t$ by integration through Eq. 8 :

$\Rightarrow z=\frac{M_{O_{3}} \int_{0}^{n_{R, c}} d n_{R, c}}{\int_{0}^{t} F_{G}\left(C_{G, i}-C_{G, o}\right) d t}=\frac{M_{O_{3}} n_{R, c}}{F_{G} \int_{0}^{t}\left(C_{G, i}-C_{G, o}\right) d t}$

The denominator was easily calculated by numerical integration using the experimental values of $C_{G, 0}$.

\subsubsection{Determination of $z$}

Whatever the temperature, the average values of the stoichiometric coefficient $(z)$ found at the end of each experiment are close to one (Table 3). Reasonable relative standard deviations (RSD) at each temperature, in the range $4.1-14 \%$, were obtained. Thus, the real value of $z$ was assumed to be one, in agreement with the initiation reactions 1 to 3 . This stoichiometric coefficient differs from the value of $1 / 2$ traditionally observed using the peroxone process (Paillard et al., 1988; Staehelin and Hoigne, 1982), but is consistent with the fact that a large tert-butanol concentration (section 3.2.3) was used to quench all the radicals formed and to avoid an overconsumption of $\mathrm{O}_{3}$ involved in the radical chain mechanism.

Table 3: Determination of the stoichiometric coefficient $z$ (average values of five experiments at each temperature).

\begin{tabular}{|cccc|}
\hline $\boldsymbol{T}\left({ }^{\circ} \mathbf{C}\right)$ & $\boldsymbol{z}$ & $\sigma_{\mathbf{z}}$ & $\boldsymbol{R S D}(\boldsymbol{\%})$ \\
\hline $\mathbf{2 0}$ & 0.96 & 0.039 & 4.1 \\
\hline $\mathbf{2 5}$ & 0.95 & 0.10 & 10 \\
\hline $\mathbf{3 0}$ & 0.94 & 0.10 & 10 \\
\hline $\mathbf{3 5}$ & 0.97 & 0.14 & 14 \\
\hline
\end{tabular}




\subsubsection{Selection of the tert-butanol concentration}

To avoid parasite reactions with the radicals induced by the ozone decomposition and to control carefully the reaction stoichiometry, the aqueous solution was spiked with tert-butanol which acts as an efficient radical scavenger in the presence of ozone (Sein et al., 2007). A sufficient tert-butanol concentration was necessary to (i) insure that the reaction rate between $\mathrm{HO}^{\circ}$ and tert-butanol was higher than the reaction rate of $\mathrm{HO}^{\circ}$ with $\mathrm{H}_{2} \mathrm{O}_{2}, \mathrm{HO}_{2}{ }^{-}$or $\mathrm{O}_{3}$ and to (ii) insure an excess of tert-butanol compared to the amount of radical produced during the experiments and then, to guarantee a perennial effect. On the one hand, several experiments carried out at 0.001 and $0.01 \mathrm{~mol} \mathrm{~L}^{-1}$ provided erroneous results. At $0.001 \mathrm{~mol} \mathrm{~L}^{-1}$, the reaction rates determined at $20^{\circ} \mathrm{C}$ were around 1 order of magnitude higher than the one expected, which might be due to an enhanced $\mathrm{O}_{3}$ transfer due to parasite reactions between $\mathrm{O}_{3}$ and radicals. Then, a concentration of $0.01 \mathrm{~mol} \mathrm{~L}^{-1}$ was not enough to control the stoichiometry of the reaction after a certain period of time (i.e. $z$ ranged between $1 / 2$ and 1), probably because the amount of tert-butanol introduced was around 4.5 times lower than the amount of $\mathrm{H}_{2} \mathrm{O}_{2}$ introduced and lower than the amount of radical produced. Thus, a total tertbutanol consumption before the end of the experiments might be observed.

Table 4: Determination of the pseudo-first order reaction constants at $20^{\circ} \mathrm{C}$ (at $t_{0}$ and $t_{f}$ corresponding to one hour of experiment) between $\mathrm{HO}^{\circ}$ and all the species in competition considering the worst conditions.

\begin{tabular}{|c|c|c|c|c|}
\hline $\begin{array}{c}\text { Competing } \\
\text { species }\end{array}$ & Tert-butanol & $\mathrm{O}_{3}$ & $\mathrm{H}_{2} \mathrm{O}_{2}$ & $\mathrm{HO}_{2}^{-}$ \\
\hline $\begin{array}{c}k_{H O} / \mathrm{i} \\
\left(\mathrm{L} \mathrm{mol}^{-1} \mathrm{~s}^{-1}\right)\end{array}$ & $\begin{array}{c}6 \times 10^{8} \\
\text { (Buxton et al., 1988) }\end{array}$ & $\begin{array}{c}(2.0 \pm 0.5) \times 10^{9} \\
\text { (Staehelin et al., } \\
1984)\end{array}$ & $\begin{array}{c}(2.7 \pm 0.3) \times 10^{7} \\
\text { (Christensen et al., } \\
\text { 1982) }\end{array}$ & $\begin{array}{c}(7.5 \pm 1.0) \times 10^{9} \\
\text { (Christensen et al., } \\
1982)\end{array}$ \\
\hline$k^{\prime}$ at $t_{0}\left(s^{-1}\right)^{a}$ & $3.0 \times 10^{7}$ & $10^{6 \mathrm{~b}}$ & $1.2 \times 10^{6 c}$ & $7.3 \times 10^{6 c}$ \\
\hline$k^{\prime}$ at $t_{\mathrm{f}}\left(\mathbf{s}^{-1}\right)$ & $2.8 \times 10^{7 d}$ & $10^{6 b}$ & $1.1 \times 10^{6 \mathrm{e}}$ & $4.6 \times 10^{5 \mathrm{e}}$ \\
\hline
\end{tabular}

\footnotetext{
${ }^{a} \mathrm{k}^{\prime}$ is the pseudo-first order reaction rate constant calculated for any species i by $\mathrm{kHO}_{\mathrm{H} / \mathrm{i}} \times[\mathrm{i}]$

${ }^{\mathrm{b}}$ Calculated with the highest interfacial ozone concentration observed $\left(\approx 5.0 \times 10^{-4} \mathrm{~mol} \mathrm{~L}^{-1}\right)$

${ }^{\mathrm{C}}$ Calculated assuming the highest $\mathrm{pH}(\approx 10.1)$ and $C_{R}=1.5 \mathrm{~g} \mathrm{~L}^{-1}$ at to

${ }^{d}$ Calculated assuming a consumption of one mol of tert-butanol per mol of $\mathrm{H}_{2} \mathrm{O}_{2}$ consumed

e Calculated assuming a final $\mathrm{pH}=8.94$ and $C_{R}=1.4 \mathrm{~g} \mathrm{~L}^{-1}$ (highest concentration and $\mathrm{pH}$ measured after $1 \mathrm{~h}$ )
} 
On the other hand, using an initial tert-butanol concentration of $0.05 \mathrm{~mol} \mathrm{~L}^{-1}$, the hydroxyl radicals should selectively react with the tert-butanol, more than with $\mathrm{O}_{3}, \mathrm{H}_{2} \mathrm{O}_{2}$ and $\mathrm{HO}_{2}{ }^{-}$, according to the values of the pseudo-first order reaction rate constants $\left(k^{\prime}\right.$ in $\left.\mathrm{s}^{-1}\right)$ computed between $\mathrm{HO}^{\circ}$ and all these species (Table 4). Indeed, the values of $k^{\prime}$ which corresponds to the reaction between $\mathrm{HO}^{\circ}$ and tert-butanol are from 4 to 60 times higher than the other values of $k^{\prime}$, even after $1 \mathrm{~h}$ of experiment. A consumption of one mol of $\mathrm{H}_{2} \mathrm{O}_{2}$ and one mol of tert-butanol and the production of one mol of $\mathrm{HO}^{\circ}$ per mol of ozone transferred were considered (Moss et al., 2008).

\subsection{Mass-transfer modeling}

The gas and the liquid phases were perfectly mixed, the process was isothermal and the gas flow rate was not affected by the ozone absorption Dang et al. (2016). A fast absorption regime with a null dissolved ozone concentration was reached $\left(C_{L}=0\right)$. Then, $J$, the molar flux of ozone transferred (mol $\mathrm{s}^{-1}$ ) through the gas-liquid interfacial area $\left(S\right.$ in $\left.\mathrm{m}^{2}\right)$, can be deduced from the mass-transfer rate and the mass-balance according to respectively Eqs 9 and 10:

$J=K_{L} S C_{L}^{e q}$

Eq. 9.

$J=F_{G} \frac{\left(C_{G, i}-C_{G, 0}\right)}{M_{O_{3}}}=\frac{1}{z} \frac{d n_{R, C}}{d t}$

$K_{L}$ is the overall liquid-phase mass-transfer coefficient $\left(\mathrm{m} \mathrm{s}^{-1}\right) . K_{L}$ depends on the gas-phase $\left(k_{G}\right.$ in $\mathrm{m} \mathrm{s}$ $\left.{ }^{1}\right)$ and liquid-phase $\left(k_{L}\right.$ in $\left.\mathrm{m} \mathrm{s}^{-1}\right)$ mass-transfer coefficients, the ozone Henry's law constant $\left(H\right.$ in Pa m ${ }^{3}$ $\mathrm{mol}^{-1}$ ) and the enhancement (or reaction) factor (E) according to Eq. 11 (Roustan, 2003):

$$
\frac{1}{K_{L}}=\frac{1}{E k_{L}}+\frac{R T}{H k_{G}}
$$

$k_{L}$ and $k_{G}$ values (Table 1 ) were previously determined with the same operating conditions (Dang et al., 2016). In Eq. 10, $C_{G}\left(\mathrm{~g} \mathrm{~m}^{-3}\right)$ and $F_{G}\left(\mathrm{~m}^{3} \mathrm{~s}^{-1}\right)$ are expressed using the volume at the working temperature and pressure. $C_{L}^{e q}$ is the ozone concentration $\left(\mathrm{mol} \mathrm{m}^{-3}\right)$ at the equilibrium with the ozone outlet gas concentration $C_{G, 0}\left(\mathrm{~g} \mathrm{~m}^{-3}\right)$ and is deduced according to the Henry's law: 
$C_{L}^{e q}=\frac{R T C_{G, 0}}{M_{O_{3}} H}$

Thus, Eqs. 13 and 14 are deduced from Eqs. 9 and 10 with the help of Eq. 12:

$$
\begin{gathered}
\frac{d n_{R, C}}{d t}=\frac{z S R T K_{L} C_{G, o}}{M_{O_{3}} H} \\
C_{G, o}=\frac{C_{G, i}}{1+\frac{K_{L} S R T}{F_{G} H}}
\end{gathered}
$$

Then $C_{G, o}$ can be replaced in Eq. 13 using Eq. 14 to lead to Eq. 15:

$$
\frac{d n_{R, C}}{d t}=\frac{z C_{G, i} F_{G}}{M_{O_{3}}}\left(1+\frac{F_{G} H}{K_{L} S R T}\right)^{-1}
$$

Eq. 16 allows to correlate directly $K_{L}$, and hence $E$, to the $\mathrm{H}_{2} \mathrm{O}_{2}$ concentration time-course.The determination of $E$ depends on the nature of the reaction(s) (reversible, irreversible, etc.) and reagents involved, on the reaction kinetics, on the reagent(s) and solute diffusion coefficients and on $k_{L}$ (van Swaaij and Versteeg, 1992). According to the reactions 1 to 3 , the reaction involved assuming an efficient scavenging of the radicals formed is a bimolecular irreversible reaction. The selected initial chemical conditions (Table 2) were advantageous to reach long-lasting (at least one hour) relevant mass-transfer and reaction rates involving a fast absorption regime. Assuming that the reactant concentration was in excess compared to the interfacial ozone concentration (fast pseudofirst order absorption regime assumption, checked in the section 3.4.3), $E$ is equal to the Hatta number $(\mathrm{Ha})$ whatever the considered mass-transfer theory (Beltrán, 1997):

$$
E=H a=\sqrt{\frac{k\left[\mathrm{HO}_{2}^{-}\right] D_{L}}{k_{L}^{2}}}=\sqrt{\frac{k C_{R} D_{L}}{k_{L}^{2} M_{R}\left(1+10^{p K A-p H}\right)}}
$$

$k$ is the reaction constant of the irreversible bimolecular reaction between $\mathrm{HO}_{2}{ }^{-}$and $\mathrm{O}_{3}\left(\mathrm{~L} \mathrm{~mol}^{-1} \mathrm{~s}^{-1}\right)$. $D_{L}$ is the ozone diffusion coefficient at infinite dilution in water $\left(\mathrm{m}^{2} \mathrm{~s}^{-1}\right) .\left[\mathrm{HO}_{2}^{-}\right]$is the bulk $\mathrm{HO}_{2}^{-}$ concentration (mol L-1) which is deduced from $\mathrm{C}_{R}$, the $\mathrm{H}_{2} \mathrm{O}_{2} / \mathrm{HO}_{2}^{-} \mathrm{pKa}$ and of the solution $\mathrm{pH}$. Thus, 
from Eqs. 11 and 16, $K_{L}$ depends on the chemical conditions $\left(C_{R}, p H\right)$, the reaction rate constant $k$ and the local gas-phase mass-transfer coefficient $\left(k_{G}\right)$ through Eq. 17:

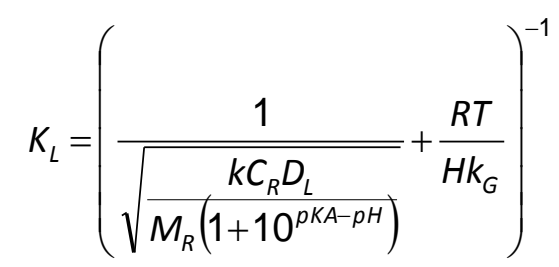

Thus, replacing Eq. 17 into Eq. 15, the time derivative of the amount of $\mathrm{H}_{2} \mathrm{O}_{2}$ consumed can be computed according to Eq. 18:

$$
\frac{d n_{R, C}}{d t}=\frac{z C_{G, i} F_{G}}{M_{O_{3}}}\left(1+\left(\frac{1}{\sqrt{\frac{k C_{R} D_{L}}{M_{R}\left(1+10^{p K A-p H}\right)}}}+\frac{R T}{H k_{G}}\right) \frac{F_{G} H}{S R T}\right)^{-1}
$$

Eq. 18 only depends on the selected operating conditions $\left(T, C_{G, i}, F_{G}\right)$ and on the varying chemical conditions $\left(C_{R}, p H\right)$. The geometry and dynamics of the reactor (through the surface area $S$ and $k_{G}$ ), the stoichiometric number $(z)$ and some physico-chemical properties $\left(H, D_{L}, p K a, O_{3}\right.$ and $\mathrm{H}_{2} \mathrm{O}_{2}$ molar masses) are also involved.

Since $n_{R, c}$ time-course was previously determined from the experiments and fitted to a second or third degree polynomial function $\left(n_{R, C}=C_{1} t^{3}+C_{2} t^{2}+C_{3} t\right.$, with $C_{1}$ to $C_{3}$ three constants $), d n_{R, C} / d t$ was easily deduced from the derivative of this polynomial function (example in Fig. 2):

$$
\frac{d n_{R, C}}{d t}=3 \times C_{1} \times t^{2}+2 \times C_{2} \times t+C_{3}
$$

Thus, for each experiment, an optimized value of $k$ was deduced according to Eq. 20 through the minimization of the least square objective function (OF) between the values of $d n_{R,} / \mathrm{d} t$ obtained theoretically through Eq. 18 and the values deduced from the experiments (Eq. 19). 
$O F=\frac{1}{n} \sum_{j=1}^{n}\left(\frac{\left(\frac{d n_{R, C}}{d t}\right)_{E q .18}^{t_{j}}-\left(\frac{d n_{R, C}}{d t}\right)_{E q .19}^{t_{j}}}{\left(\frac{d n_{R, C}}{d t}\right)_{\text {Eq.19 }}^{t_{j}}}\right)^{2}$ with $n$ the number of time-path $\Delta \mathrm{t}$

Eq. 20.

Then, it was possible to deduce both the theoretical time-courses of $n_{R, C}$ through Eq. 21 and $C_{R}$ through Eq. 22:

$$
\begin{aligned}
& n_{R, c}^{t+\Delta t}=n_{R, c}^{t}+\frac{\Delta t}{2}\left(\left(\frac{d n_{R, C}}{d t}\right)_{\mathrm{Eq} .18}^{t+\Delta t}+\left(\frac{d n_{R, C}}{d t}\right)_{\mathrm{Eq} .18}^{t}\right) \text { with } n_{R, c}^{t_{0}}=0 \\
& C_{R}^{t+\Delta t}=\frac{C_{R}^{t_{0}} V^{t_{0}}-M_{R} n_{R, c}^{t+\Delta t}-M_{R} n_{R, I}^{t+\Delta t}}{V^{t+\Delta t}}
\end{aligned}
$$

The experimental and theoretical values of $C_{R}$ were in good agreement (example at $20^{\circ} \mathrm{C}$ in Fig. 1.a). The theoretical time-course of $C_{G, o}$ was also deduced from Eq. 18 and the mass-balance through Eq. 4 (examples at $20^{\circ} \mathrm{C}$ in the Fig. 1.b). The time path $\Delta t$ of $120 \mathrm{~s}$ was sufficient for a good accuracy. In Eq. 18, $D_{L}$ was computed with the empirical correlation of Johnson and Davis (Beltrán, 2004; Johnson and Davis, 1996; Masschelein, 2000):

$$
D_{L}=1.1 \times 10^{-6} \exp \left(-\frac{1896}{T[K]}\right)
$$

The $\mathrm{H}_{2} \mathrm{O}_{2} / \mathrm{HO}_{2}^{-} p K a$ was calculated according to the results of Evans and Uri (1949) (Evans and Uri, 1949). The $\mathrm{pH}$ was computed by second or third degree polynomial functions fitted to the experimental values with determination coefficients $R^{2}$ higher than $99 \%$ (Example Fig. 2).

\subsection{Determination of the reaction rate constant and the activation energy}

\subsubsection{Reaction rate constant}

Table 5: Determination of the reaction rate constant considering both the Ferre-Aracil et al. and Perry's correlations to determine $H$. The relative error (RE) is calculated between the experimental values of $k$ and the values deduced from the Arrhenius law (Eqs 24 and 25). 


\begin{tabular}{|c|c|c|c|c|}
\hline$T\left({ }^{\circ} \mathrm{C}\right)$ & 20 & 25 & 30 & 35 \\
\hline$p K a$ & 11.75 & 11.65 & 11.55 & 11.45 \\
\hline \multicolumn{5}{|c|}{$H$ calculated from the correlation of Ferre-Aracil et al. (2015) } \\
\hline $10^{-6} \times k$ experimental $\left(\mathrm{L} \mathrm{mol}^{-1} \mathrm{~s}^{-1}\right)$ & 2.40 & 2.81 & 4.23 & 5.68 \\
\hline $10^{-6} \times \sigma_{k}(\mathrm{~L}$ & 0.50 & 0.44 & 0.34 & 0.37 \\
\hline RSD & 21 & 16 & 8 & 7 \\
\hline $10^{-6} \times \mathrm{k}$ model ( $\mathrm{L} \mathrm{mo}$ & 2.27 & 3.09 & 4.16 & 5.56 \\
\hline RE (\%) & 5.8 & 9.0 & 1.7 & 2.2 \\
\hline \multicolumn{5}{|c|}{$H$ calculated from the correlation of Perry et al. (1973) } \\
\hline $10^{-6} \times \mathrm{k}$ experimental $\left(\mathrm{L} \mathrm{mol}^{-1} \mathrm{~s}^{-1}\right)$ & 1.91 & 2.64 & 4.68 & 7.31 \\
\hline $10^{-6} \times \sigma_{\mathrm{k}}\left(\mathrm{L} \mathrm{mol}^{-1} \mathrm{~s}^{-1}\right)$ & 0.40 & 0.41 & 0.40 & 0.37 \\
\hline RSD (\%) & 21 & 16 & 8 & 7 \\
\hline $10^{-6} \times k$ model $\left(\mathrm{L} \mathrm{mol}^{-1}\right.$ & 1.80 & 2.90 & 4.59 & 7.17 \\
\hline RE (\%) & 5.7 & 9.0 & 1.9 & 2.0 \\
\hline
\end{tabular}

According to Eq. 19, the ozone mass-transfer depends on the Henry's law constant in water, whose the value is still rather controversial in the literature. Following the recommendation of Dang et al. (2016), both the correlations of Perry (1973) and Ferre-Aracil et al. (2016) were considered in the calculations (Dang et al., 2016; Ferre-Aracil et al., 2015; Mandel, 2010; Perry et al., 1973). Thus, for the five experiments achieved at each temperature, two different values of the reaction rate constant $k$ have been determined following the numerical resolution procedure presented on the section 3.3. The average values of $k$ (Table 5) increased from $2.40 \times 10^{6} \mathrm{~L} \mathrm{~mol}^{-1} \mathrm{~s}^{-1}$ at $20^{\circ} \mathrm{C}$ to $5.68 \times 10^{6} \mathrm{~L}$ $\mathrm{mol}^{-1} \mathrm{~s}^{-1}$ at $35^{\circ} \mathrm{C}$ using the Ferre-Aracil et al. correlation (2015) and from $1.91 \times 10^{6} \mathrm{~L} \mathrm{~mol}^{-1} \mathrm{~s}^{-1}$ at $20^{\circ} \mathrm{C}$ to $7.31 \times 10^{6} \mathrm{~L} \mathrm{~mol}^{-1} \mathrm{~s}^{-1}$ at $35^{\circ} \mathrm{C}$ using the data of Perry (1973). The relative standard deviations at the different temperatures studied are rather low, in the range $7-21 \%$. The relative error (RE) of the five experiments at each temperature are represented in Fig. 3. Except for the experiment \#4 whose the corresponding RE are particularly low, RE for all the experiments are balanced either above or below the averages, indicating that all these experiments are adequate and respect the pseudo-first order regime assumption, otherwise a systemic error would have been observed. 


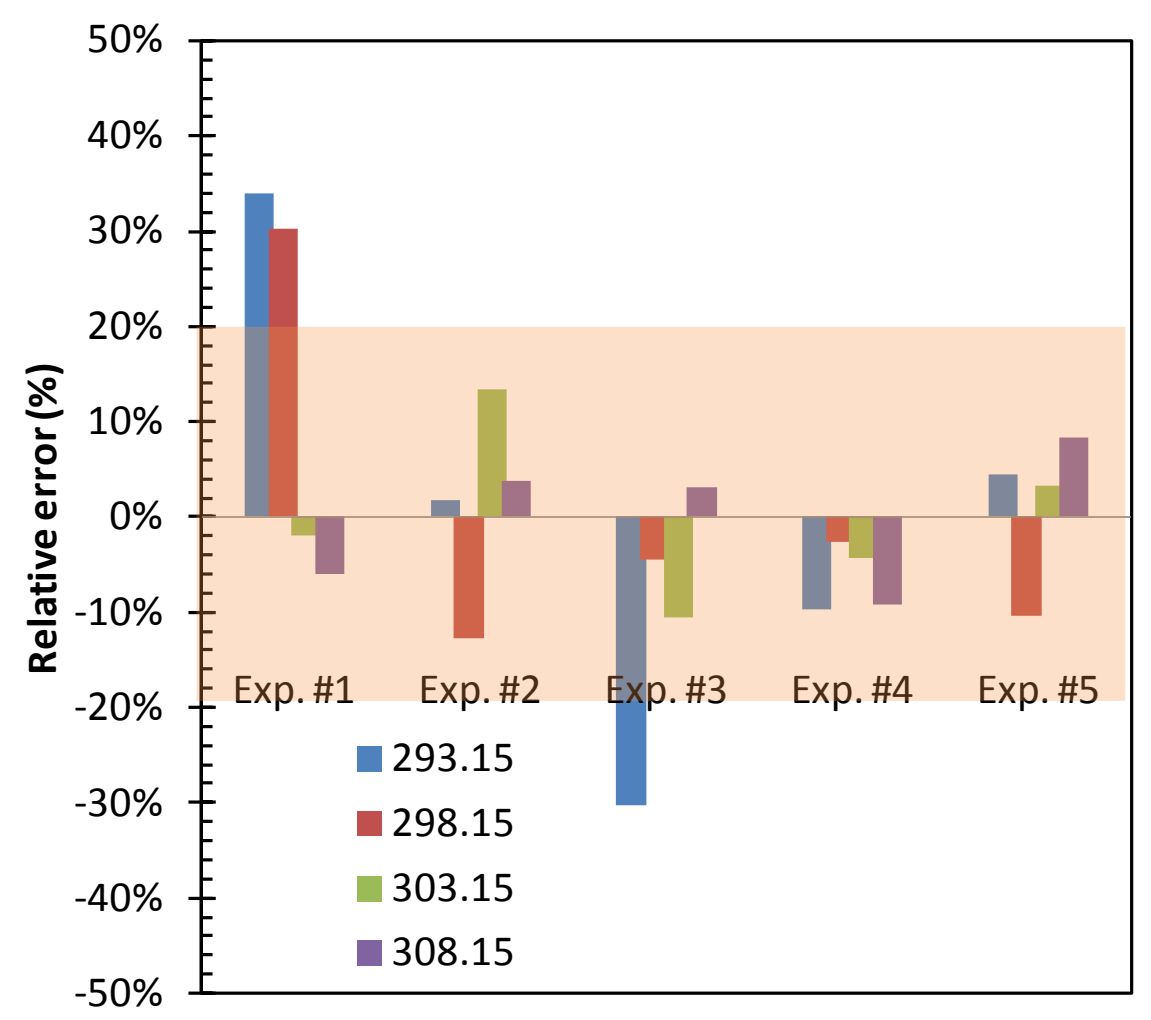

Figure 3: Relative error of the five experiments at the different temperatures. The average experimental values of $k$ are considered for the calculation.

Whatever the correlation considered to calculate the Henry's law constant, the reaction rate constant follows undoubtedly the Arrhenius law (Fig. 4), with determination coefficients $R^{2}$ equal to $97.2 \%$ and $98.8 \%$. Thus, the values of $k$ can be extrapolated at any temperature in the range $20-35^{\circ} \mathrm{C}$ according to respectively Eq. 24 when $H$ is estimated by the data of Perry (1973) and Eq. 25 when $H$ is estimated by the correlation of Ferre-Aracil et al. (2015):

$$
\begin{aligned}
& k\left[\mathrm{Lmol}^{-1} \mathrm{~s}^{-1}\right]=3.69 \times 10^{18} \exp \left(-\frac{69.1 \times 10^{3}}{R T[K]}\right) \\
& k\left[\mathrm{Lmol}^{-1} \mathrm{~s}^{-1}\right]=2.29 \times 10^{14} \exp \left(-\frac{44.9 \times 10^{3}}{R T[K]}\right)
\end{aligned}
$$



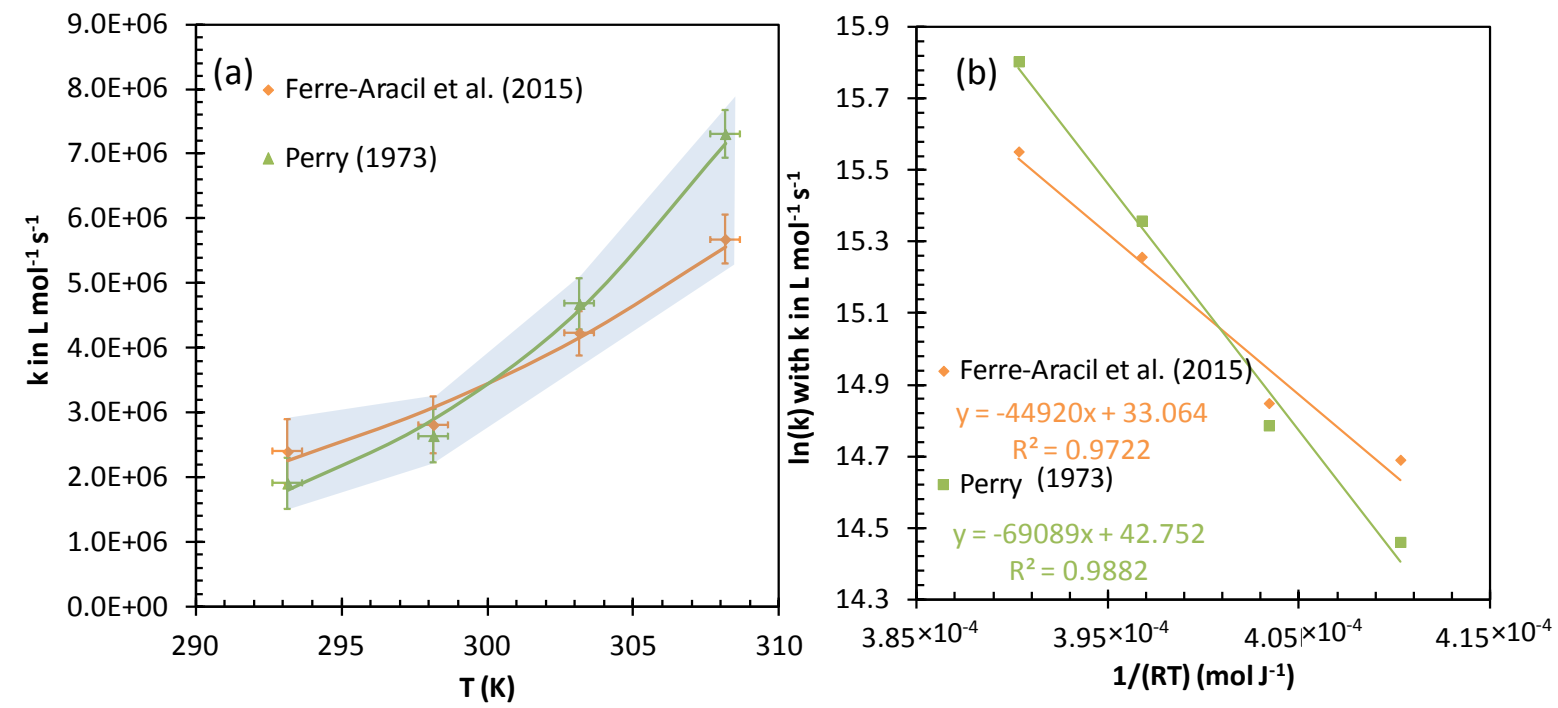

Figure 4: (a) Evolution of $k$ with the temperature considering both the Perry (1973) and Ferre-

Aracil et al. (2015) correlations. The error bar represents the standard deviations of the experimental values. The straight curves represent the prediction according to the Arrhenius law

(Eqs 24 and 25). (b) Linear regressions corresponding to the Arrhenius law.

The temperature evolution of $k$ is sharper considering the Perry's data (1973), with an activation energy of $69.1 \mathrm{~kJ} \mathrm{~mol}^{-1}$ whereas the activation energy considering the correlation of Ferre-Aracil et al. (2015) is $35 \%$ lower, equal to $44.9 \mathrm{~kJ} \mathrm{~mol}^{-1}$. The relative error between the experimental average values of $k$ and those of the Arrhenius law are in the range $1.7 \%\left(30^{\circ} \mathrm{C}\right)-9 \%\left(25^{\circ} \mathrm{C}\right)$.

\subsubsection{Comparison with the data of the literature at $20^{\circ} \mathrm{C}$}

The $k$ values determined at $20^{\circ} \mathrm{C}$ for the two considered correlations (Ferre-Aracil et al. (2015) and Perry (1973)) can be compared to three values reported in the literature (Sein et al., 2007; Staehelin and Hoigne, 1982; Tomiyasu et al., 1985). Since slightly different values of the $\mathrm{H}_{2} \mathrm{O}_{2} / \mathrm{HO}_{2}^{-} p K a$ were used by these authors (from 11.65 to $11.8,11.75$ in this study), the values reported on the Table 4 have been corrected taking into account the $p K a$ considered by these authors (red and green bars on Fig. 5). The best agreement is obtained with the value of $2.2 \times 10^{6} \mathrm{~L} \mathrm{~mol}^{-1} \mathrm{~s}^{-1}$ found by Tomiyasu et al. (1985), especially when $k$ was determined using the correlation of Ferre-Aracil et al. (2015) with a relative error of $14 \%$ ( $32 \%$ considering the Perry's data (1973)). The experimental values assuming the Ferre-Aracil et al. correlation (Perry's correlation) are respectively 40 (52\%) and 44\% (56\%) lower 
than the values of Staehelin and Hoigné (1982) and Sein et al. (2007). Nonetheless, the error bars almost overlap. Taking into account the large reaction rate involved, such a slight discrepancy is acceptable.

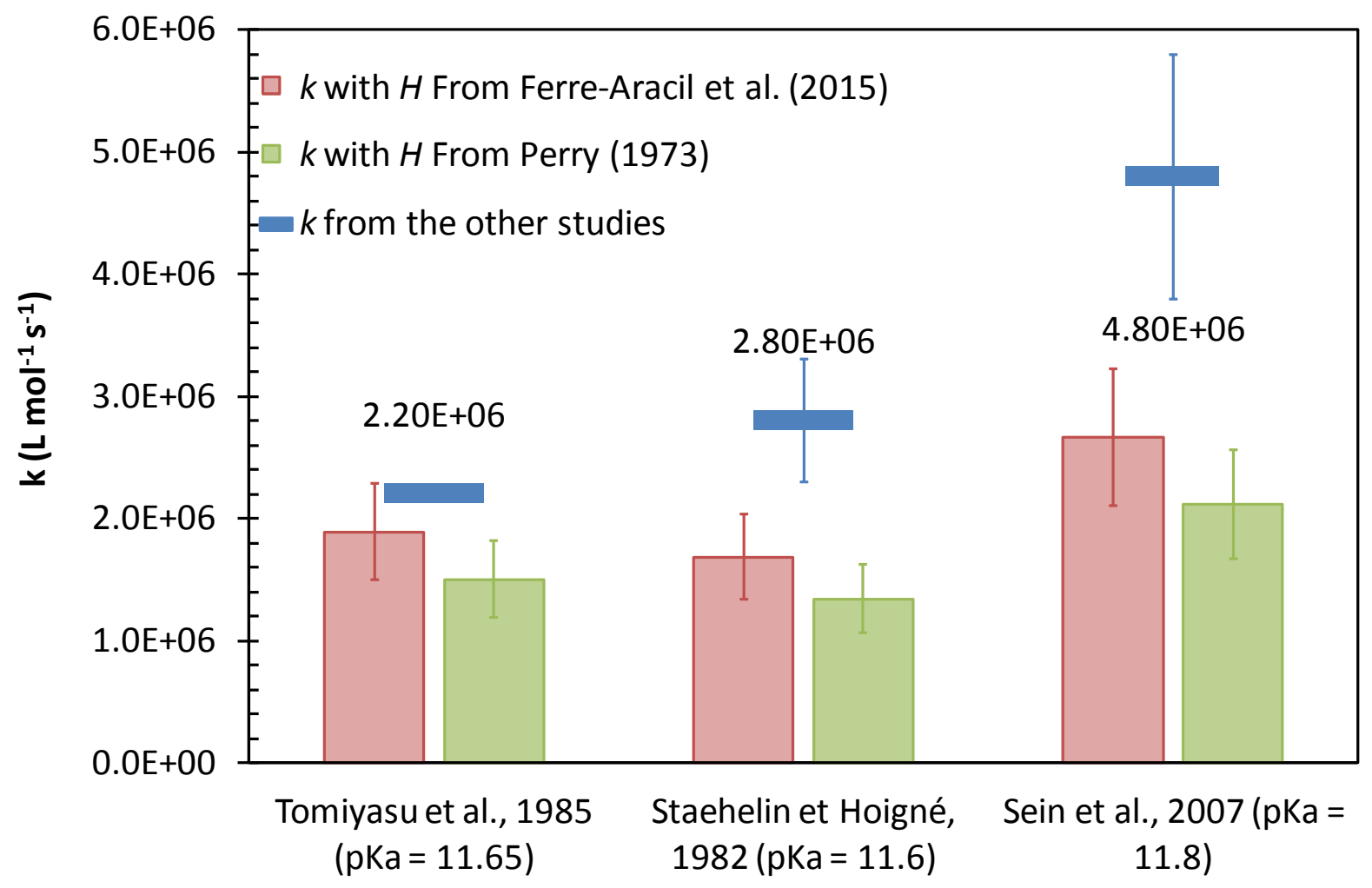

Figure 5: Comparison of the experimental values of $k$ determined considering the Ferre-Aracil et al. and Perry's correlations to the values of the literature. The experimental value of $k\left(2.40 \times 10^{6}\right.$ $\mathrm{L} \mathrm{mol}^{-1} \mathrm{~s}^{-1}$ (Ferre-Aracil et al., 2015) and $1.91 \times 10^{6} \mathrm{~L} \mathrm{~mol}^{-1} \mathrm{~s}^{-1}$ (Perry, 1973)) were corrected taking into account the values of the $\mathrm{H}_{2} \mathrm{O}_{2}$ pKa considered in the other studies.

\subsubsection{Pseudo-first order regime justification}

The mathematical treatment developed in the section 3.3 is based on the crucial assumption of a pseudo-first order regime, which implies that the diffusive rate of the reactant $\left(\mathrm{HO}_{2}{ }^{-}\right)$is significantly higher than the reaction rate, allowing to assume a constant reactant concentration in the liquid film surrounding the gas-liquid interface (Beltrán, 2004). Even if the reaction between $\mathrm{O}_{3}$ and $\mathrm{HO}_{2}^{-}$can be considered as an irreversible bimolecular reaction, allowing to use the Hatta number defined as Eq. 
16 for the enhancement factor calculation, the $\mathrm{H}_{2} \mathrm{O}_{2}$ proton transfer reaction with $\mathrm{HO}^{-}$must be considered, since it favorably contributes to the reformation of $\mathrm{HO}_{2}^{-}$in the liquid film:

$$
\mathrm{H}_{2} \mathrm{O}_{2}+\mathrm{HO}^{-} \underset{\mathrm{k}_{-}=1.92 \times 10^{6} \mathrm{~s}^{-1}}{\stackrel{\mathrm{k}_{+}=5 \times 10^{8} \mathrm{~L} \mathrm{~mol}^{-1} \mathrm{~s}^{-1}}{\rightleftharpoons}} \mathrm{HO}_{2}^{-}+\mathrm{H}_{2} \mathrm{O}
$$

The value of reaction rate constant $k_{+}$at $20^{\circ} \mathrm{C}$ was proposed by Christensen et al. (1982). Thus, the value of $k$. was deduced from the $\mathrm{H}_{2} \mathrm{O}_{2} / \mathrm{HO}_{2}^{-} p K a$ and the water ion product ( $p K=14.17$ at $20^{\circ} \mathrm{C}$ ). Then, the disappearance rate of $\mathrm{HO}_{2}^{-}\left(R_{\mathrm{HO}_{2}^{-}}\right.$in $\left.\mathrm{mol} \mathrm{L}^{-1} \mathrm{~s}^{-1}\right)$ would be written:

$$
\left.R_{\mathrm{HO}_{2}^{-}}=k_{-}\left[\mathrm{HO}_{2}^{-}\right]+k\left[\mathrm{HO}_{2}^{-}\right] \mathrm{O}_{3}\right]-k_{+}\left[\mathrm{H}_{2} \mathrm{O}_{2}\right]\left[\mathrm{HO}^{-}\right]
$$

Whatever the $\mathrm{pH}$, the term corresponding to the reaction between $\mathrm{O}_{3}$ and $\left.\mathrm{HO}_{2}^{-}\left(\mathrm{k}^{-} \mathrm{HO}_{2}^{-}\right]\left[\mathrm{O}_{3}\right]\right)$ is 1600 times lower than the two other equal terms. This calculation was achieved assuming the worst case, i.e. the highest ozone concentration at the liquid interface $\left(\approx 5 \times 10^{-4} \mathrm{~mol} \mathrm{~L}^{-1}\right)$. Thus, the reaction of $\mathrm{HO}_{2}{ }^{-}$with $\mathrm{O}_{3}$ would be the rate limiting step and the $\mathrm{HO}_{2}{ }^{-}$concentration would remain at any location of the gas liquid film at the equilibrium with the $\mathrm{H}_{2} \mathrm{O}_{2}$ concentration. Therefore, mainly $\mathrm{H}_{2} \mathrm{O}_{2}$ and, in a lower extent $\mathrm{HO}_{2}^{-}$, should diffuse in the liquid film prior to the reaction with $\mathrm{O}_{3}$. Thus, $E_{i}$, the instantaneous enhancement factor according to the Danckwerts' surface renewal theory is calculated taking into account $\mathrm{C}_{\mathrm{R}}$ instead of $\left[\mathrm{HO}_{2}^{-}\right]$(Beltrán, 2004; DeCoursey, 1974):

$E_{i}=\sqrt{\frac{D_{L}}{D_{R}}}+\frac{C_{R}}{z C_{L}^{*}} \sqrt{\frac{D_{R}}{D_{L}}}$

$C_{L}^{*}$ is the ozone concentration at the interface $\left(\mathrm{mol} \mathrm{L}^{-1}\right)$ deduced from Eq. 29 considering $C_{L}=0$ for $\mathrm{Ha}$ $\geq 5$ (fast absorption regime) (Biard and Couvert, 2013):

$$
C_{L}^{*}=\left(1+\frac{R T E k_{L}}{H k_{G}}\right)^{-1} C_{L}^{e q}=\left(1+\frac{R T H a k_{L}}{H k_{G}}\right)^{-1} C_{L}^{e q}
$$


The $\mathrm{H}_{2} \mathrm{O}_{2}$ diffusion coefficient $\left(D_{R}\right)$ was in the range $2.0 \times 10^{-9} \mathrm{~m}^{2} \mathrm{~s}^{-1}$ at $20^{\circ} \mathrm{C}-2.75 \times 10^{-9} \mathrm{~m}^{2} \mathrm{~s}^{-1}$ at $35^{\circ} \mathrm{C}$ (Kan and Huling, 2009). Two numerical conditions must be respected for a fast pseudo-first order absorption regime : (i) a Hatta number higher than roughly 5 and (ii) a Hatta number significantly lower than $E_{i}$ (at least two times) (Beltrán, 2004). Due to the $\mathrm{H}_{2} \mathrm{O}_{2}$ consumption and $\mathrm{pH}$ decreasing during the experiments (section 3.1), both the Hatta number and the enhancement factor decreased with time.

Considering the values of $k$ determined (section 3.4.1), the Hatta number considering all the experiments was in the range 3-310 whatever the temperature. The few times the Hatta number was lower than 5, the corresponding points were unconsidered in the numerical resolution in order to do not affect the calculation of the objective function (Eq. 20). Finally, the condition $E_{i} / H a>2$ was respected at any time.

\subsection{Sensitivity analysis}

In order to assess the influence of the different inputs $(I)$ on the output $(O)$, which is here $k$ the second order reaction rate constant, the elasticity index has been calculated (Mandel, 2010; Vilmain et al., 2014). As long as the pseudo-first order regime assumption is respected, several classes of inputs can be identified: the inputs corresponding to physico-chemical properties $\left(H, D_{L}\right)$, those corresponding to the experimental conditions $\left(C_{R}, S, T, F_{G}, C_{G, i}\right), k_{G}$ which has been previously experimentally determined and finally $\mathrm{d} n_{R, c} / \mathrm{d} t$, which is the fitting variable (Dang et al., 2016).

The elasticity index was calculated for varying values of the $\mathrm{pH}$ (in the range 8-10, Fig. 6) and varying value of $C_{R}$ (in the range $0.5-1.5 \mathrm{~g} \mathrm{~L}^{-1}$ for $\mathrm{pH}=10$, Fig. 7). Since the elasticity index for the different inputs is poorly influenced by $C_{R}$, only the average values are represented in Fig. 7 (the error bars corresponding to the standard deviations are not visible). The determination of $k$ is mainly sensitive to the $p H$ and the $p K a\left(19<E I_{p H}<23\right.$ and $E I_{p K a}$ around 27). The high influence of the $p K a$ was emphasized by the comparison with various authors (Fig. 5). Thus, it is recommended to use the 
same $p K a$ values than the one considered to determine $k$. The $\mathrm{pH}$ probe was calibrated daily and corrected by a temperature compensation. A systematic error in the $\mathrm{pH}$ measurement is then unlikely. Nonetheless, the high sensitivity to the $\mathrm{pH}$ affects the experimental uncertainty of $k$, which can justify the relative standard deviations observed for the determination of $k$ (Fig. 4.a).

The elasticity indexes corresponding to $S, C_{G, O}, C_{R}, D_{L}$ and $H$ are nearly equal to 2 , meaning that an error of $10 \%$ in one of this input would affect by $20 \%$ the value of $k$ determined. $H$ and $D_{L}$ are two physico-chemical properties. Two correlations for $H$ have been considered allowing to define a window for the $k$ value evolution with the temperature (Fig. 4.a). $D_{L}$ value is controversial in the literature with a relative difference of $30 \%$ considering the empirical correlations of Johnson and Davis (1996) and Matrozov et al. (1976). The correlation of Johnson and Davis, which provides the best agreement with the semi-empirical correlation of Wilke-Chang, was taken into account but we cannot dismiss a potential uncertainty on it. The gas-liquid interfacial area $(S)$ was deduced with a low uncertainty from the vessel diameter measured with a sliding caliper. $C_{G, o}$ was measured using an on-line ozone analyzer with an experimental uncertainty lower than $0.5 \%$ according to the supplier (BMT, Germany). The zero of this analyzer was regularly controlled. $C_{R}$ was measured by the iodometric method with a low relative uncertainty. Therefore, the influence of $C_{R}$ and $C_{G, 0}$ in the determination of $k$ would remain limited. Finally, $k$ was poorly sensitive to the gas phase masstransfer coefficient $\left(E I_{k_{G}}<0.5\right)$. Rather low mass-transfer enhancements were involved, allowing to locate the mass-transfer resistance mainly in the liquid phase. Thus, the experimental uncertainty on this measured variable poorly influences the determination of $k$ (Dang et al., 2016). Finally, the determination of $k$ is insensitive to $k_{L}$ and $D_{R}$ when using the pseudo-first order absorption regime. 


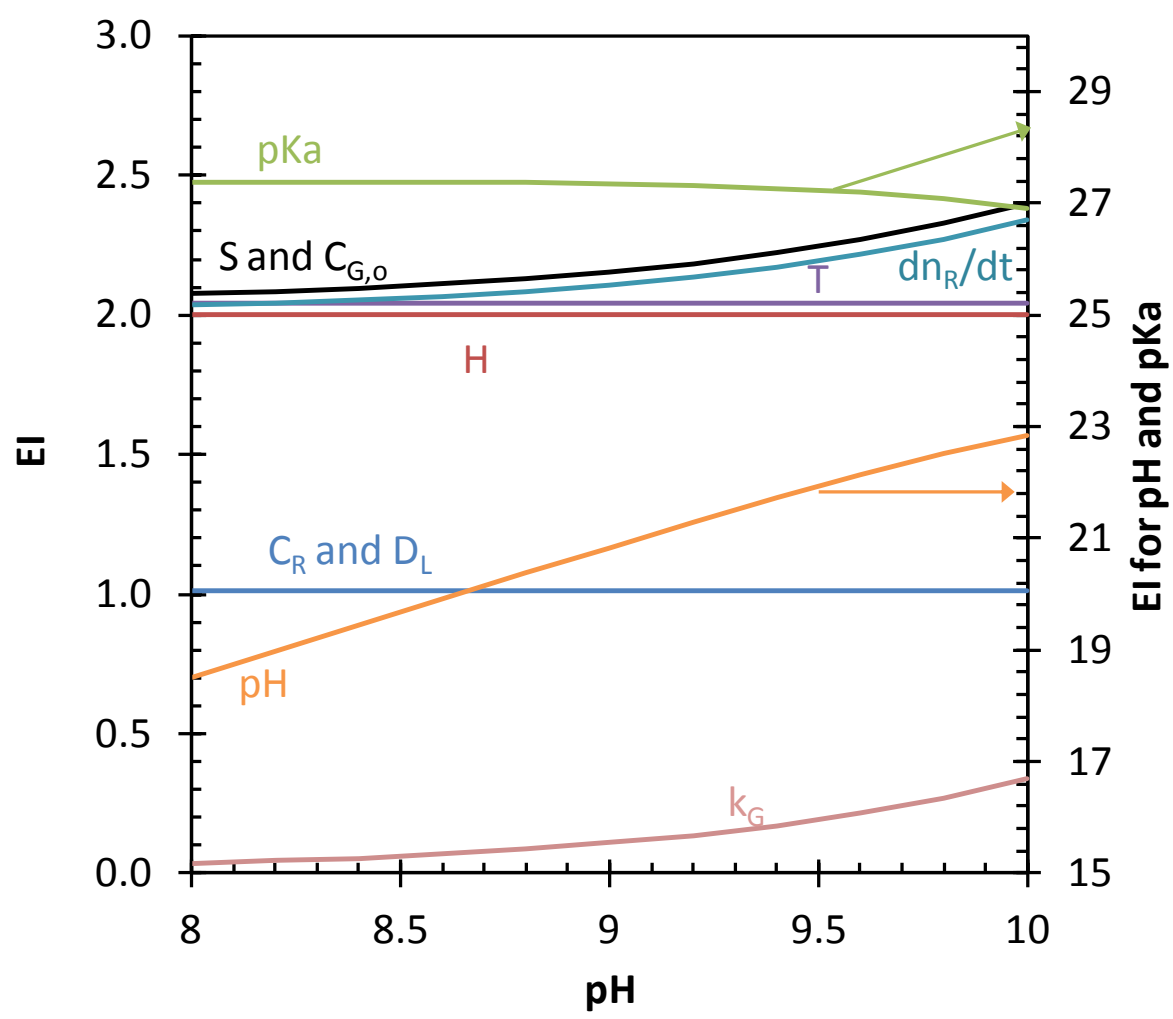

Figure 6: Evolution of the elasticity index of different inputs with the $p H$ (with $C_{R}=1.5 \mathrm{~g} \mathrm{t}^{-1}$ ).

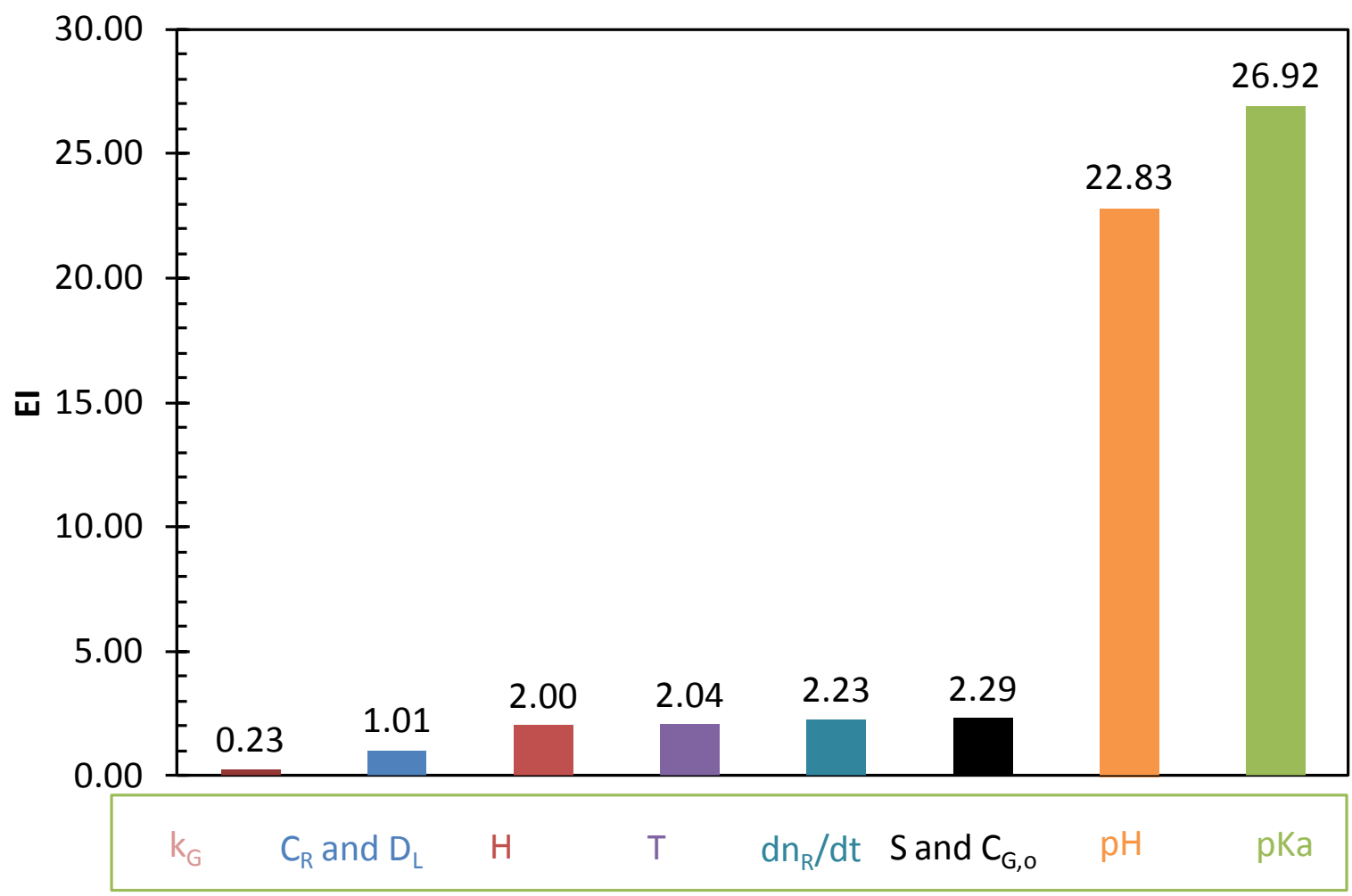

Figure 7: Average elasticity index of different inputs at $p H=10$ for $0.5<C_{R}<1.5 \mathrm{~g} \mathrm{~L}^{-1}$ (with $C_{R}=$ $\left.1.5 \mathrm{~g} \mathrm{~L}^{-1}\right)$. 


\section{Conclusion}

The rate constant of the reaction of the hydroperoxide anion (the $\mathrm{H}_{2} \mathrm{O}_{2}$ conjugated base) with molecular ozone was determined in the temperature range from 20 to $35^{\circ} \mathrm{C}$ by reactive absorption. A stirred-cell reactor operated semi-continuously was used for this purpose. The operating conditions (an initial $\mathrm{H}_{2} \mathrm{O}_{2}$ concentration around $1.5 \mathrm{~g} \mathrm{~L}^{-1}$ and an initial $\mathrm{pH}$ in the range 9.5-10) were selected to reach a fast pseudo-first order absorption regime. Tert-butanol was added at a concentration of 0.05 $\mathrm{mol} \mathrm{L}^{-1}$ to scavenge the radicals formed allowing to prevent parasite reactions.

From the ozone mass balance and from the hydrogen peroxide concentration time-course, a consumption of one mol of ozone per mol of hydrogen peroxide was confirmed, in agreement with the stoichiometry of the initiation reaction.

Thus, from the hydrogen peroxide concentration and $\mathrm{pH}$ time-courses, which were correlated to the ozone mass-transfer rate assuming a pseudo-first order absorption regime, the reaction rate constant was deduced at $20,25,30$ and $35^{\circ} \mathrm{C}$. The values found at $20^{\circ} \mathrm{C}\left(1.91\right.$ or $2.40 \times 10^{6} \mathrm{~L} \mathrm{~mol}^{-1} \mathrm{~s}^{-1}$, depending on the considered correlation to calculate the ozone Henry's law constant) were consistent with the other values reported in the literature. Thus, the evolution of the reaction constant was correlated to the temperature using the Arrhenius law. An activation energy in the range $45-69 \mathrm{~kJ} \mathrm{~mol}^{-1}$ was determined.

\section{Acknowledgments}

The authors wish to thank the Vietnam Ministry of Education and Training and Campus France for their financial supports (PhD thesis grants $\left.N^{\circ} 793312 F \& 793315 L\right)$. 


\section{References}

Acero, J.L., Von Gunten, U., 2001. Characterization of oxidation processes : ozonation and the AOP $\mathrm{O}_{3} / \mathrm{H}_{2} \mathrm{O}_{2}$. Journal of the American Water Works Association 93, 90-100.

Beltrán, F.J., 1997. Theoretical aspects of the kinetics of competitive first reactions of ozone in the $\mathrm{O}_{3} / \mathrm{H}_{2} \mathrm{O}_{2}$ and $\mathrm{O}_{3} / \mathrm{UV}$ oxidation processes. Ozone Science and Engineering 19, 13 - 38.

Beltrán, F.J., 2004. Ozone reaction kinetics for water and wastewater systems. Lewis Publisher, Boca Raton.

Beltrán, F.J., Fernández, L.A., Álvarez, P., Rodriguez, E., 1998. Comparison Of Ozonation Kinetic Data From Film and Danckwerts Theories. Ozone: Sci. Eng. 20, 403-420.

Biard, P.-F., Couvert, A., 2013. Overview of mass transfer enhancement factor determination for acidic and basic compounds absorption in water. Chem. Eng. J. 222, 444-453.

Bin, A.K., Roustan, M., 2000. Mass transfer in ozone reactors, IOA International specialised symposium, fundamental and engineering concepts for ozone reactor design, Toulouse, pp. 99-131.

Buehler, R.E., Staehelin, J., Hoigne, J., 1984a. Ozone Decomposition in Water Studied by Pulse Radiolysis $1 . \mathrm{HO}_{2}{ }^{\circ} / \mathrm{O}_{2}{ }^{-\circ}$ and $\mathrm{HO}_{3}{ }^{\circ} / \mathrm{O}_{3}{ }^{\circ-}$ as Intermediates - Correction. Journal of Physical Chemistry 88, 5450-5450.

Buehler, R.E., Staehelin, J., Hoigne, J., 1984b. Ozone decomposition in water studied by pulse radiolysis. 1. Perhydroxyl $\left(\mathrm{HO}_{2}\right) /$ hyperoxide $\left(\mathrm{O}_{2}^{-0}\right)$ and $\mathrm{HO}_{3}{ }^{\circ} / \mathrm{O}_{3}^{-0}$ as intermediates. Journal of Physical Chemistry 88, 2560-2564.

Buxton, G.V., Greenstock, C.L., Helman, W.P., Ross, A.B., Tsang, W., 1988. Critical review of rate constants for reactions of hydrated electrons, hydrogen atoms and hydroxyl radicals $\left(\mathrm{OH}^{*} / \mathrm{O}^{--}\right)$in aqueous solution. Journal of Physical and Chemical Reference Data 17, 513-886.

Cardona, S.C., López, F., Abad, A., Navarro-Laboulais, J., 2010. On bubble column reactor design for the determination of kinetic rate constants in gas-liquid systems. Can. J. Chem. Eng. 88, 491-502. 
Christensen, H., Sehested, K., Corfitzen, H., 1982. Reactions of hydroxyl radicals with hydrogen peroxide at ambient and elevated temperatures. The Journal of Physical Chemistry 86, 1588-1590.

Dang, T.T., Biard, P.-F., Couvert, A., 2016. Assessment of a Stirred-Cell Reactor Operated Semicontinuously for the Kinetic Study of Fast Direct Ozonation Reactions by Reactive Absorption. Ind. Eng. Chem. Res. 55, 8058-8069.

DeCoursey, W.J., 1974. Absorption with chemical reaction: development of a new relation for the Danckwerts model. Chem. Eng. Sci. 29, 1867-1872.

Evans, M., Uri, N., 1949. The dissociation constant of hydrogen peroxide and the electron affinity of the HO 2 radical. Transactions of the Faraday Society 45, 224-230.

Ferre-Aracil, J., Cardona, S., Navarro-Laboulais, J., 2015. Determination and validation of Henry's Constant for Ozone in Phosphate Buffers using different analytical methodologies. Ozone: Sci. Eng. 37, 106-118.

Fischbacher, A., von Sonntag, J., von Sonntag, C., Schmidt, T.C., 2013. The $\bullet \mathrm{OH}$ Radical Yield in the H2O2 + O3 (Peroxone) Reaction. Environ. Sci. Technol. 47, 9959-9964.

Gardoni, D., Vailati, A., Canziani, R., 2012. Decay of Ozone in Water: A Review. Ozone: Sci. Eng. 34, 233-242.

Glaze, W.H., Kang, J.W., 1989. Advanced oxidation processes. Description of a kinetic model for the oxidation of hazardous materials in aqueous media with ozone and hydrogen peroxide in a semibatch reactor. Ind. Eng. Chem. Res. 28, 1573-1580.

Glaze, W.H., Kang, J.W., Chapin, D.H., 1987. Chemistry of water treatment processes involving ozone, hydrogen peroxide and ultraviolet radiation. Ozone Science and Engineering 9, 335-352.

Johnson, P.N., Davis, R.A., 1996. Diffusivity of Ozone in Water. J. Chem. Eng. Data 41, 1485-1487.

Kan, E., Huling, S.G., 2009. Effects of temperature and acidic pre-treatment on Fenton-driven oxidation of MTBE-spent granular activated carbon. Environ. Sci. Technol. 43, 1493-1499. 
Luzi, C., Bressa, S., Mazza, G., Barreto, G., 2014. A supporting formulation for introducing gas-liquid reactions. Ed. Chem. Eng. 9, 50-66.

Mandel, P., 2010. Modelling ozonation processes for disinfection by-product control in potable water treatment : from laboratory to industrial units, ENSCR. PhD thesis, Université de Rennes 1, Rennes, p. 292.

Mandel, P., Roche, P., Wolbert, D., 2014. Large-Scale Experimental Validation of a Model for the Kinetics of Ozone and Hydroxyl Radicals with Natural Organic Matter. Ozone: Sci. Eng. 36, 73-85.

Masschelein, W.J., 2000. Fundamental properties of ozone in relation to water sanitation and environmental applications, IOA International specialised symposium, fundamental and engineering concepts for ozone reactor design, Toulouse, pp. 1-21.

Matrozov, V., Kachtunov, S., Tregunov, B., Stepanov, A., 1976. Experimental determination of the molecular diffusion coefficient of ozone in water. Zh. Prikl. Khim 49, 1070-1073.

Merényi, G., Lind, J., Naumov, S., Sonntag, C.v., 2010a. Reaction of Ozone with Hydrogen Peroxide (Peroxone Process): A Revision of Current Mechanistic Concepts Based on Thermokinetic and Quantum-Chemical Considerations. Environ. Sci. Technol. 44, 3505-3507.

Merényi, G., Lind, J., Naumov, S., von Sonntag, C., 2010b. The Reaction of Ozone with the Hydroxide Ion: Mechanistic Considerations Based on Thermokinetic and Quantum Chemical Calculations and the Role of HO4- in Superoxide Dismutation. Chemistry - A European Journal 16, 1372-1377.

Moss, J.T., Berkowitz, A.M., Oehlschlaeger, M.A., Biet, J., Warth, V., Glaude, P.-A., Battin-Leclerc, F., 2008. An Experimental and Kinetic Modeling Study of the Oxidation of the Four Isomers of Butanol. The Journal of Physical Chemistry A 112, 10843-10855.

Paillard, H., Brunet, R., Dore, M., 1988. Optimal conditions for applying an ozone-hydrogen peroxide oxidizing system. Water Res. 22, 91-103.

Perry, R.H., Green, D.W., Maloney, J.O., 1973. Chemical Engineers handbook. McGraw-Hill Professional, New-York. 
Roustan, M., 2003. Transferts gaz-liquide dans les procédés de traitement des eaux et des effluents gazeux. Lavoisier, Paris.

Sein, M.M., Golloch, A., Schmidt, T.C., von Sonntag, C., 2007. No Marked Kinetic Isotope Effect in the Peroxone $\left(\mathrm{H}_{2} \mathrm{O}_{2} / \mathrm{D}_{2} \mathrm{O}_{2}+\mathrm{O}_{3}\right)$ Reaction: Mechanistic Consequences. Chem. Phys. Chem. 8, 2065-2067.

Sotelo, J.L., Beltrán, F.J., Gonzalez, M., 1990. Ozonation of aqueous solutions of resorcinol and phloroglucinol. 1. Stoichiometry and absorption kinetic regime. Ind. Eng. Chem. Res. 29, 2358-2367.

Sotelo, J.L., Beltrán, F.J., Gonzalez, M., Garcia-Araya, J.F., 1991. Ozonation of aqueous solutions of resorcinol and phloroglucinol. 2. Kinetic study. Ind. Eng. Chem. Res. 30, 222-227.

Staehelin, J., Buehler, R.E., Hoigne, J., 1984. Ozone decomposition in water studied by pulse radiolysis. 2. Hydroxyl and hydrogen tetroxide $\left(\mathrm{HO}_{4}{ }^{\circ}\right)$ as chain intermediates. Journal of Physical Chemistry 88, 5999-6004.

Staehelin, J., Hoigne, J., 1982. Decomposition of ozone in water: rate of initiation by hydroxide ions and hydrogen peroxide. Environ. Sci. Technol. 16, 676-681.

Taube, H., Bray, W.C., 1940. Chain Reactions in Aqueous Solutions Containing Ozone, Hydrogen Peroxide and Acid. J. Am. Chem. Soc. 62, 3357-3373.

Tomiyasu, H., Fukutomi, H., Gordon, G., 1985. Kinetics and mechanism of ozone decomposition in basic aqueous solution. Inorg. Chem. 24, 2962-2966.

Vaidya, P.D., Kenig, E.Y., 2007. Gas-Liquid reaction kinetics: a review of determination methods. Chem. Eng. Commun. 194, 1543-1565.

van Swaaij, W.P.M., Versteeg, G.F., 1992. Mass transfer accompanied with complex reversible chemical reactions in gas-liquid systems: an overview. Chem. Eng. Sci. 47, 3181-3195.

Vilmain, J.-B., Courousse, V., Biard, P.-F., Azizi, M., Couvert, A., 2014. Kinetic study of hydrogen sulfide absorption in aqueous chlorine solution. Chem. Eng. Res. Des. 92, 191-204.

Von Gunten, U., 2003. Ozonation of drinking water: Part I. Oxidation kinetics and product formation. Water Res. 37, 1443-1467. 
Von Sonntag, C., Von Gunten, U., 2012. Chemistry of ozone in water and wastewater treatment: From basic principles to applications. IWA Publishing, p. 320. 